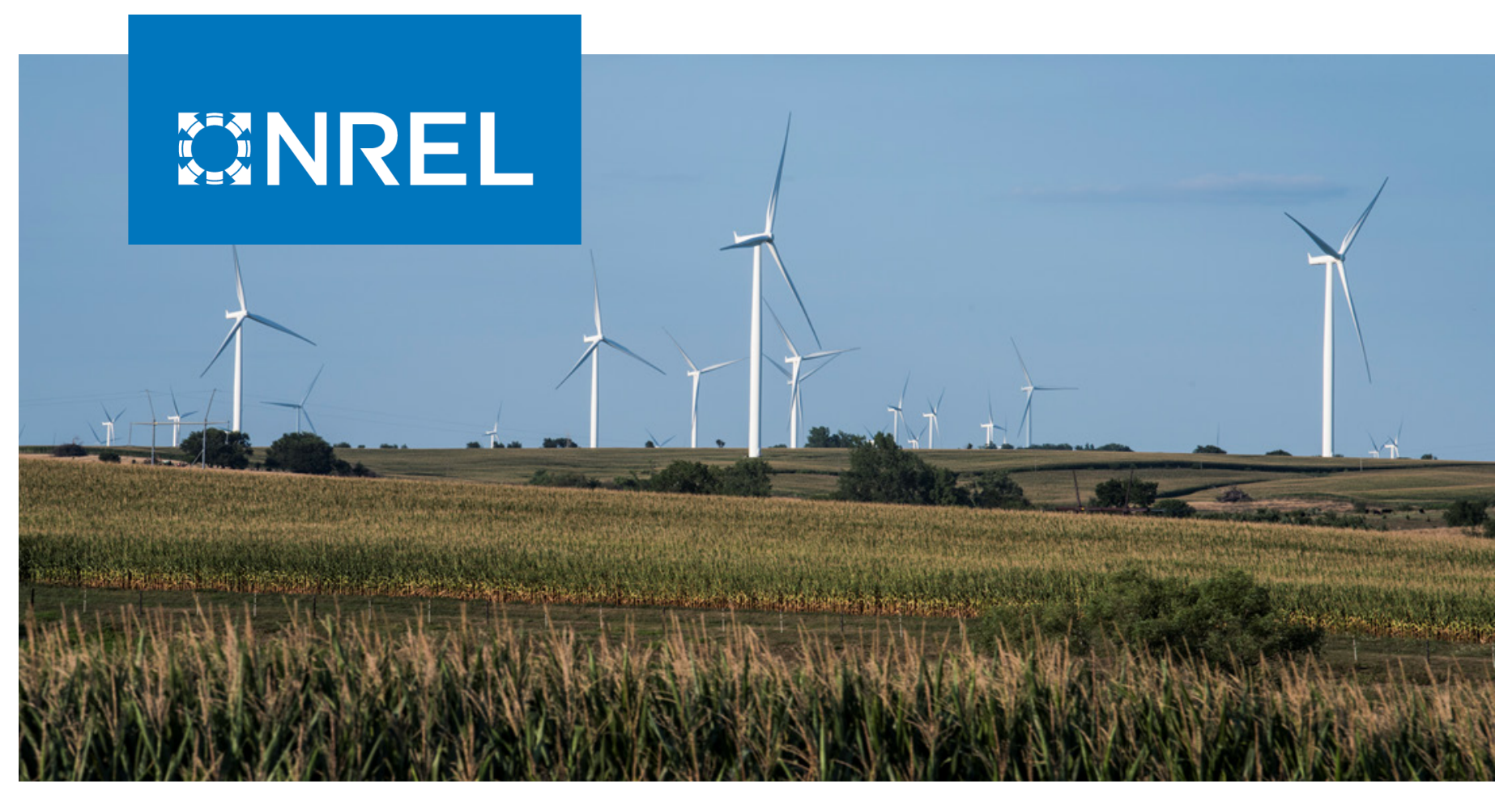

\title{
The Wind Energy Workforce in the United States: Training, Hiring, and Future Needs
}

David Keyser ${ }^{1}$ and Suzanne Tegen ${ }^{2}$

1 National Renewable Energy Laboratory

2 Center for the New Energy Economy

NREL is a national laboratory of the U.S. Department of Energy Office of Energy Efficiency \& Renewable Energy

Operated by the Alliance for Sustainable Energy, LLC

This report is available at no cost from the National Renewable Energy Laboratory (NREL) at www.nrel.gov/publications.

\section{Technical Report} NREL/TP-6A20-73908 July 2019 


\title{
GHREL
}

The Wind Energy Workforce in the United States: Training, Hiring, and Future Needs

\section{David Keyser ${ }^{1}$ and Suzanne Tegen ${ }^{2}$}

\author{
1 National Renewable Energy Laboratory \\ 2 Center for the New Energy Economy
}

\section{Suggested Citation}

Keyser, David, and Suzanne Tegen. 2019. The Wind Energy Workforce in the United States: Training, Hiring, and Future Needs. Golden, CO: National Renewable Energy Laboratory. NREL/TP-6A20-73908. https://www.nrel.gov/docs/fy19osti/73908.pdf.

NREL is a national laboratory of the U.S. Department of Energy Office of Energy Efficiency \& Renewable Energy Operated by the Alliance for Sustainable Energy, LLC

This report is available at no cost from the National Renewable Energy Laboratory (NREL) at www.nrel.gov/publications.

Contract No. DE-AC36-08GO28308
Technical Report NREL/TP-6A20-73908 July 2019

National Renewable Energy Laboratory 15013 Denver West Parkway Golden, CO 80401 303-275-3000 • www.nrel.gov 


\section{NOTICE}

This work was authored [in part] by the National Renewable Energy Laboratory, operated by Alliance for Sustainable Energy, LLC, for the U.S. Department of Energy (DOE) under Contract No. DE-AC36-08GO28308. Funding provided by U.S. Department of Energy Office of Energy Efficiency and Renewable Energy Wind Energy Technologies Office. The views expressed herein do not necessarily represent the views of the DOE or the U.S. Government.

This report is available at no cost from the National Renewable Energy Laboratory (NREL) at www.nrel.gov/publications.

U.S. Department of Energy (DOE) reports produced after 1991 and a growing number of pre-1991 documents are available free via www.OSTI.gov.

Cover Photo by Dennis Schroeder: NREL 47301.

NREL prints on paper that contains recycled content. 


\section{Disclaimer}

This work was authored by the National Renewable Energy Laboratory (NREL), operated by Alliance for Sustainable Energy, LLC, for the U.S. Department of Energy (DOE) under Contract No. DE-AC36-08GO28308. Funding provided by DOE's Wind Energy Technologies Office. The views expressed in this document do not necessarily represent the views of DOE or the U.S. Government. The U.S. Government retains and the publisher, by accepting the document for publication, acknowledges that the U.S. Government retains a nonexclusive, paid-up, irrevocable, worldwide license to publish or reproduce the published form of this work, or allow others to do so, for U.S. Government purposes. 


\section{Acknowledgments}

NREL authors acknowledge and appreciate the representatives from academic and training institutions as well as businesses who participated in research surveys leading to the important results documented in this report. Phil Jordan and his team at BW Research gathered industry data, and Jeremy Stefek from NREL provided fact-checking and reviews. Michael Leventhal of Clear Path Communications provided original data analysis. We appreciate the support and guidance from Amber Passmore, Maggie Yancey, and Jocelyn Brown-Saracino of DOE's Wind Energy Technologies Office. Liz Hartman of DOE and Ruth Baranowski of High Desert Technical Communications provided editing support. Brian Smith, Paul Veers, and Ian BaringGould of NREL, Kirsten Verclas of DOE, Robin P. Krakowsky, E.d.D. of Johnson and Wales University, and Katherine Heriot Hoffer, Ph.D. of the Center for the New Energy Economy served as reviewers.

\section{List of Acronyms and Abbreviations}

DOE U.S. Department of Energy

EIA U.S. Energy Information Administration

GW gigawatt

JEDI Jobs and Economic Development Impacts

NREL National Renewable Energy Laboratory

O\&M operations and maintenance

STEM science, technology, engineering, and math 


\section{Executive Summary}

Employment in the wind industry in the United States increased 32\% from 2015 to 2016 (DOE 2017) and 5.6\% from 2016 to 2017 (NASEO 2018) compared to $1.8 \%$ and $1.6 \%$ in non-farm employment growth nationally (BLSa 2018). In 2017, wind energy technician was the secondfastest growing occupation in the United States (DOE 2017), following solar installer at number one. The rapid growth in the wind industry workforce can largely be attributed to the installation of new wind turbines, but the number of operations-phase jobs is also increasing for existing plants. Wind power capacity in the United States has more than tripled in the past decade, and as of 2018 , wind generation made up $6.6 \%$ of total electricity generation in the United States (EIA 2019a).

Future wind industry growth scenarios modeled by the U.S. Department of Energy in the Wind Vision report (DOE 2015) show potential industry expansion under certain market conditions at levels that would require additional education and training programs for the domestic wind industry to continue to grow. Findings from the Wind Vision show that if Wind Vision deployment levels were reached, the United States would require many new wind energy education and training programs - with scenarios ranging from several hundred to more than 1,000 new programs - to reach a growth scenario supporting $20 \%$ of U.S. electricity from wind power by $2030 .{ }^{1}$ The U.S. Energy Information Administration forecasts that wind power will grow by 12\% in 2019 and 14\% in 2020 (EIA 2019b).

An available and qualified workforce is essential for any industry. For the workforce to grow, career options need to be communicated as early as the high school level as young people consider potential occupations and educational programs. The wind power industry provides well-paying jobs in rural America as well as in urban locations. Employment opportunities include construction, manufacturing, professional, and trade workers. Educational requirements for wind energy jobs range from high school diplomas to Ph.D.s and post-graduate professional degrees to vocational degrees and apprenticeships, as detailed in this report. As shown in Figure ES-1, the wind industry supports a broad array of occupations, led by trade workers, engineers, and wind technicians.

To better understand the wind industry workforce, hiring needs, and educational pathways, researchers surveyed wind industry employers and educational institutions that offered degrees or certificates in wind energy or renewable energy with some coursework dedicated to wind. They received 247 completed surveys from wind industry employers and 50 completed surveys from representatives of educational institutions. The surveys revealed that $68 \%$ of wind industry firm representatives surveyed had difficulty hiring across most occupations. Twenty-five percent of firms searched outside of the United States to find candidates with appropriate skills and experience, which some employers consider lacking among domestic candidates. At the same time, survey results showed that people who graduate from wind energy educational programs often do not enter the wind industry upon graduation - the majority find employment outside of the wind industry. In addition, some educational and training institutions with wind or renewable energy-specific programs reported difficulty filling courses.

\footnotetext{
${ }^{1}$ The number will depend on graduation rates and how full programs are. The Wind Vision scenario referenced is called the Central Study Scenario (DOE 2015).
} 

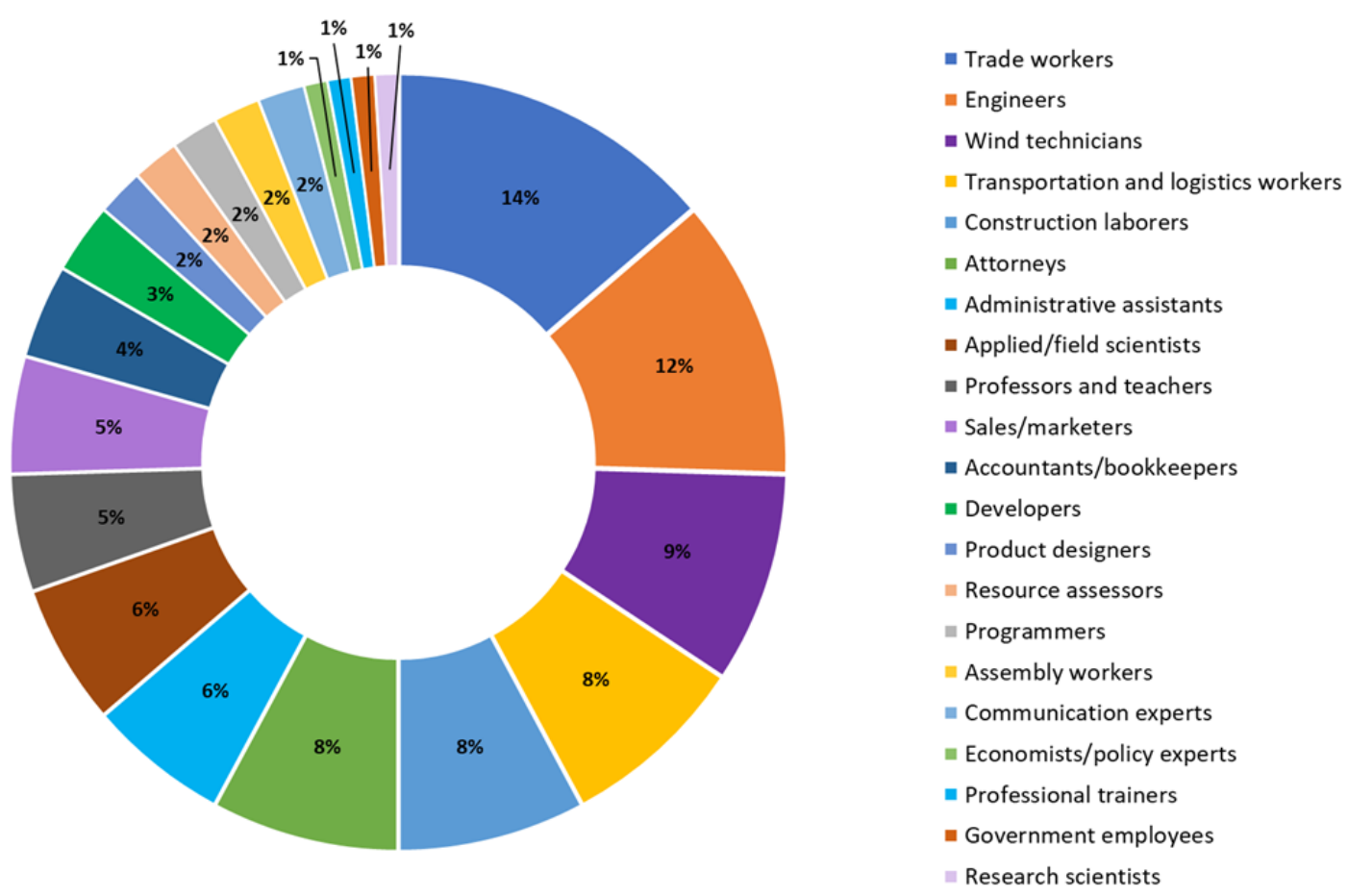

Figure ES-1. 2016 wind energy occupations in the United States (according to industry surveys with 249 firms)

The difficulty of employers identifying well qualified candidates while wind and renewable energy graduates report difficulty finding jobs in the wind industry suggests a potential gap in the wind industry workforce. Narrowing this workforce gap - decreasing hiring difficulty while increasing graduates' ability to find jobs in the wind industry - could reduce recruiting costs, better satisfy employer needs, and grow the domestic wind workforce. Narrowing the gap would simultaneously help educational institutions more efficiently fill classrooms and communicate wind industry career options to potential students.

There are some initiatives to increase awareness about wind energy occupations. For example, the U.S. Department of Energy supports initiatives such as the Wind for Schools Project ${ }^{2}$ and the Collegiate Wind Competition ${ }^{3}$ to engage and educate teachers and students about the wind industry.

\footnotetext{
${ }^{2}$ For more information about the Wind for Schools Project, visit: https://windexchange.energy.gov/windforschools

${ }^{3}$ For more information about the Collegiate Wind Competition, visit:

https://www.energy.gov/eere/collegiatewindcompetition/collegiate-wind-competition
} 


\section{Table of Contents}

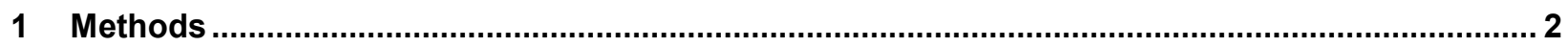

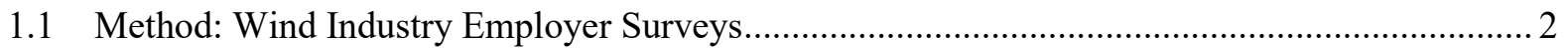

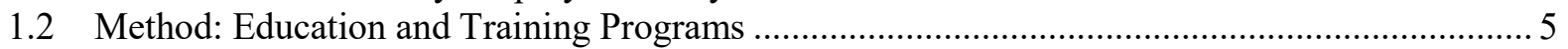

1.3 Method: Wind Workforce Estimates: New Jobs for One Wind Vision Scenario .......................... 5

1.4 Method: Estimated Number of Graduates Needed by Degree Type .......................................... 5

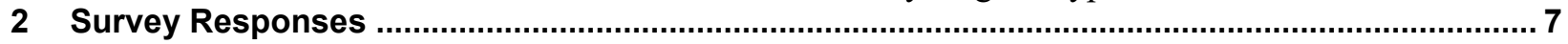

2.1 Employer Experiences: Hiring in the Wind Industry ..................................................... 7

2.2 Workforce Demographics: Women, Minorities, and Veterans in the Wind Industry ................. 16

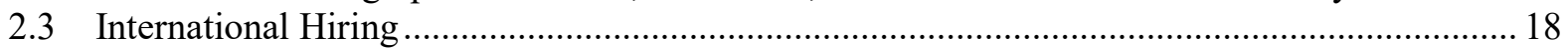

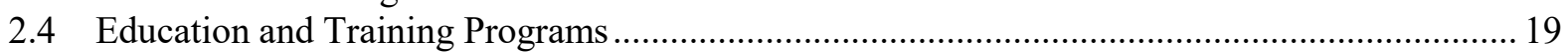

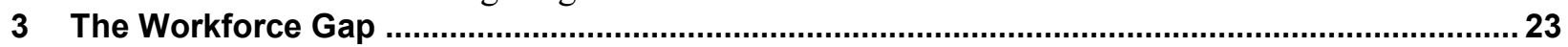

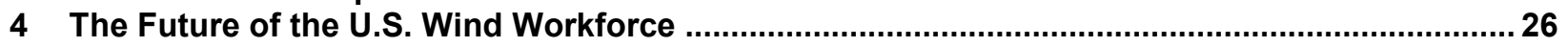

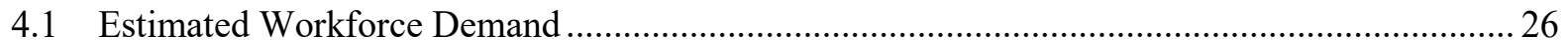

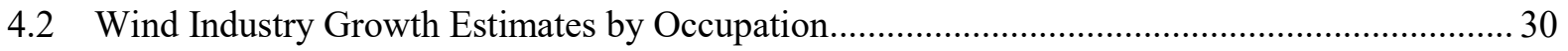

4.3 Wind Workforce Educational Needs Based on a Wind Vision Scenario.................................... 33

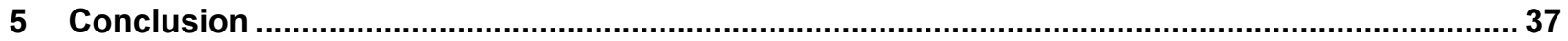

5.1 The Gap: How Is the United States Rising to the Challenge? ............................................... 38

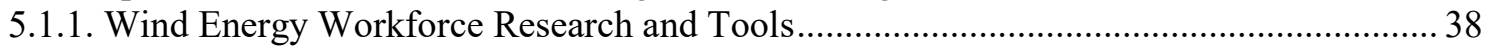

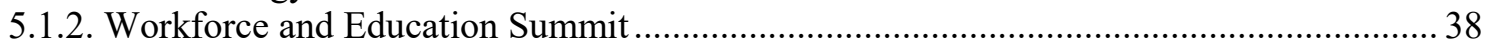

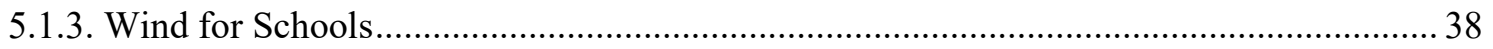

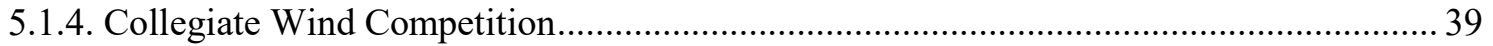

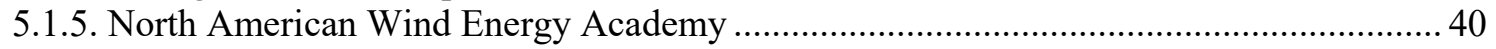

5.1.6 Domestic Wind Workforce Programs Outside of the U.S. Department of Energy ............ 40

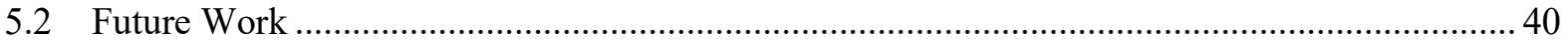

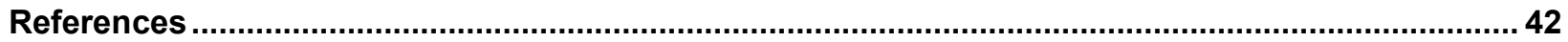

Appendix A: Estimate of U.S. Wind-Specific Degree Programs ..................................................... 44

Appendix B: BW Research Method for Estimating Today's Wind Power Employees ......................46

Appendix C: Alignment with DOE Jobs Report ........................................................................... 48

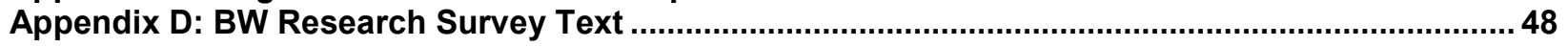




\section{List of Tables}

Table 1. Wind Industry Occupations Included in the Report.............................................................. 4

Table 2. Level of Difficulty in Finding Qualified Applicants (by Occupation) ...................................... 9

Table 3. Preferred Educational Attainments for New Hires ............................................................... 11

Table 4. Importance of Levels of Required or Preferred Wind Energy-Specific Training and Education. 13

Table 5. Work Experience: Importance of Occupational Experience and Wind-Specific Experience....... 15

Table 6. Percentage of Women, Ethnic Minorities, and Veterans in the U.S. Wind Energy Workforce ... 17

Table 7. Employers' Perceptions of U.S. Applicants Compared to Similarly Educated and Experienced

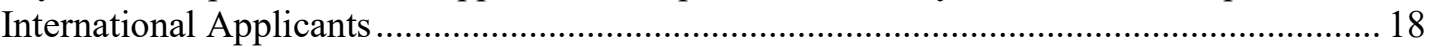

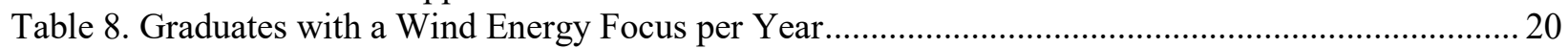

Table 9. Increasing the Number of Graduates without Additional Resources.......................................... 21

Table 10. Percentage of Graduates Entering Wind Energy ............................................................... 22

Table 11. Percent of Workforce Occupations Based on Wind Market Segment ...................................... 27

Table 12. Maximum Annual New Hires Needed by Occupation Possessing Wind-Specific* Degrees to

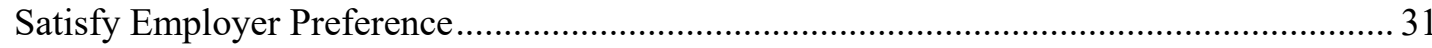

Table 13. Baseline and Gap Reduction Cases: Percentage of Graduates Entering Wind Industry and Number of Graduates per Program per Year .......................................................................... 33

Table 14. Supply and Demand for Graduates with Wind Energy-Specific Degrees (Baseline Case) ........ 34 Table 15. Supply and Demand for Graduates with Wind Energy Specific Degrees (Gap Reduction Case)

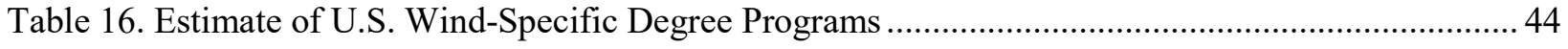

Table 17. Math Used to Estimate Program Needs ..................................................................................... 45

\section{List of Figures}

Figure ES-1. 2016 wind energy occupations in the United States (according to industry surveys with 249 firms)

Figure 1. How to interpret the Sparklines depicting preferred educational attainment for new hires in

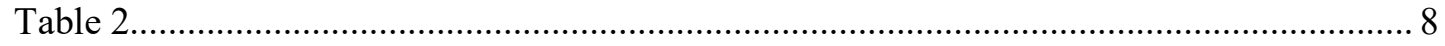

Figure 2. Consideration of non-U.S. applicants by U.S. firms and the countries of origin identified ........ 18

Figure 3. Reasons why graduates did not enter wind industry .......................................................... 23

Figure 4. Percentage of types of degree programs in which fewer than half of students enter the wind

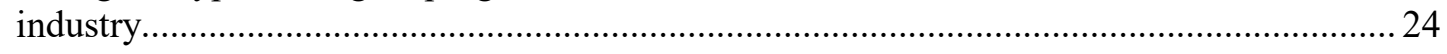

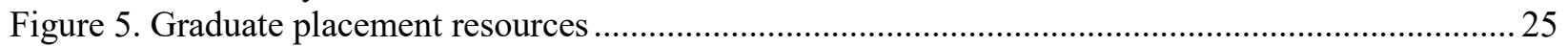

Figure 6. The Wind Vision Study Central Scenario........................................................................ 26

Figure 7. Land-based wind energy workforce (O\&M jobs) that would be supported by the Wind Vision

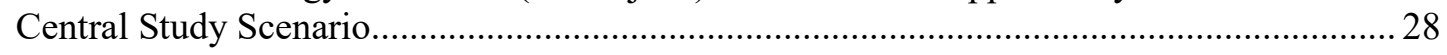

Figure 8. Estimated growth of land-based wind energy workforce (installation jobs) ............................. 29

Figure 9. Estimate of new hires needed by U.S. wind energy industry ............................................... 29

Figure 10. Students inspect wiring and electrical components on the small wind turbine they designed and built for the DOE Collegiate Wind Competition. Photo by Dennis Schroeder, NREL .......... 40 


\section{Introduction}

As part of an in-depth look at the U.S. wind energy workforce, researchers at the National Renewable Energy Laboratory (NREL) published A National Skills Assessment of the U.S. Wind Industry in 2012 (Leventhal and Tegen 2013). This report enumerated the size of the wind workforce by occupation; the types of education, training, and experience that employers seek when hiring; and the educational and training programs available to train this workforce. It concluded that the future growth of the wind workforce would require parallel growth in the number and size of educational and training programs if this workforce were to fulfill the hiring preferences of employers in the industry and according to the potential wind development scenario laid out in the U.S. Department of Energy's (DOE's) Wind Vision study (DOE 2015). ${ }^{4}$

In 2017, NREL researchers conducted a large survey to gather wind energy industry and educational institution data and performed an analysis to follow up on the report published in 2013. In addition to collecting updated data, this survey expanded on the original by including estimates of female, ethnic minority, and military veteran participation in the wind workforce. Researchers also asked educators to assess their institution's ability to increase the number of wind energy graduates without adding staff or classroom space. Finally, educators provided qualitative feedback on issues including international and domestic hiring and whether educational institutions have sufficient resources to recruit wind energy students to their programs or to help them gain employment post-graduation.

The report is intended to be a resource for a broad array of organizations interested in understanding the size, composition, and potential growth of the wind energy workforce and educational systems in the United States. Further, we hope that this information can help identify opportunities to improve the efficiency and effectiveness the pathway from education to employment, bringing together employers and educators so that those wanting to work in the wind energy industry and those looking for qualified candidates can more easily connect. These connections will help lead to the qualified workforce needed to innovate, install, operate, and maintain wind energy systems of the future. DOE's Wind Energy Technologies Office seeks to better understand and address the need for a highly qualified future workforce by providing funding support for several initiatives, including the Collegiate Wind Competition and Wind for Schools project, described in more detail in Section 5.

\footnotetext{
${ }^{4}$ DOE's Wind Vision study is one exploration of potential growth of the wind industry. The report explores a range of futures under which wind generation meets a growing amount of U.S. electricity demand. The report includes wind resource variability and costs of other renewable and non-renewable technologies, providing a comprehensive picture of how wind could supply an increasing percentage of power over time. This percentage increases from $10 \%$ in 2020 to $35 \%$ by 2050 . Leventhal and Tegen (2013) was published prior to the Wind Vision study and used an expansion scenario from the 20\% Wind Energy by 2030: Increasing Wind Energy's Contribut to U.S. Electricity Supply report (DOE 2008).
} 


\section{Methods}

This report provides 2017 data on the U.S. wind energy workforce and supporting educational and training programs. ${ }^{5}$ The research followed the same general method as the 2013 report (Leventhal and Tegen) and added elements important to the labor force, including additional analysis and an examination of why some graduates are not finding jobs in the wind industry.

\subsection{Method: Wind Industry Employer Surveys}

Researchers surveyed representatives from companies across a broad spectrum of the wind energy industry to understand what credentials they preferred when hiring new employees, how these preferences varied across occupations, and how difficult it was to find qualified candidates. NREL contracted with BW Research Partners to perform the survey, which were completed online and by telephone (to reach those who did not respond online).

Surveys were requested from companies that operated in the utility-scale, land-based wind sector, as it is the largest segment of the wind industry in the United States. Researchers did not include offshore or distributed wind firms due to the current limited level of offshore wind deployment in the United States and the significantly different skills needed in much of the distributed wind market. Future research could include offshore wind and distributed wind.

After issuing 1,835 requests, researchers received 247 completed surveys from wind industry organizations. ${ }^{6}$ Of these, $57 \%$ had one U.S. business location focused on wind energy while the others had multiple locations. ${ }^{7}$ The surveys were completed by human resource managers or those in similar positions who were qualified to answer questions relating to their company's staffing and hiring practices. Company representatives were asked to self-identify from a list of nine industry segments. The nine segments are:

1. Manufacturing (including component parts)

2. Research and development

3. Education, training, and advocacy

4. Government and regulatory

5. Construction

6. Development and siting

7. Transportation and logistics

8. Finance, legal, and insurance

\footnotetext{
5 This report follows the same basic structure and analytical method of the 2013 report. While there are differences between the 2013 and 2017 reports, such as the details of how some data were collected, and the current report collects additional information not gathered in the 2013 study, overall these reports have much in common. This report does not offer direct comparisons of methodological details, data, or conclusions between the two reports.

6 The sample is a combination of businesses known to be in the wind industry and a random sample of businesses in industries known to contain wind businesses. For further information on the methodology, see the U.S. Energy Employment Report (DOE 2017).

${ }^{7}$ Respondents from companies with multiple locations were asked if they would provide information only for their location or for all of their company's U.S. locations within the wind industry. If a respondent could only answer staffing questions for one site out of many, their responses were extrapolated upward to account for all of their company's locations; this situation only occurred for $11 \%$ of responses.
} 


\section{Operations and asset management.}

After providing information on how many people their company employed overall, as well as within the wind-focused portion of their business, respondents were asked to identify which occupations were most prevalent within their industry segment. They were then asked a series of questions for each occupation concerning credentials they prefer when hiring, including educational achievements and work experience. A copy of the questionnaire is available in Appendix D of this report.

The nine industry segments are shown above, and the 24 occupations are shown in Table 1 . To limit the survey length, researchers requested a company's hiring preferences for the four occupations with the highest levels of employment. ${ }^{8}$ The sample size of responses for each occupation is shown below. Two occupations possess small sample sizes (fewer than 10 firms) within this study. Responses for these occupations may be less representative of the true wind industry population due to these small sample sizes; hence the reader should be cautious when drawing conclusions for these two occupations (construction laborers and government regulatory workers).

\footnotetext{
${ }^{8}$ To reduce the possibility of bias, the survey did not allow respondees to choose which occupations they reported difficulty filling. This prevented respondees from solely choosing and reporting on occupations that are difficult to fill.
} 
Table 1. Wind Industry Occupations Included in the Report

\begin{tabular}{|c|c|c|}
\hline & $\begin{array}{l}\text { Number of Companies } \\
\text { Providing Responses } \\
\text { for These Occupations }\end{array}$ & $\begin{array}{l}\text { Average Number of } \\
\text { Employees in This } \\
\text { Occupation per Company }\end{array}$ \\
\hline Administrative and clerical workers & 133 & 3 \\
\hline Sales and marketing professionals & 112 & 3 \\
\hline $\begin{array}{l}\text { Accountants, bookkeepers, and finance } \\
\text { professionals }\end{array}$ & 102 & 2 \\
\hline Electrical and mechanical engineers & 69 & 5 \\
\hline Communications and public relations professionals & 61 & 2 \\
\hline Attorneys & 50 & 3 \\
\hline Trade workers (electricians, welders, etc.) & 50 & 17 \\
\hline Programmers and computer scientists & 44 & 3 \\
\hline Economists and policy experts & 41 & 2 \\
\hline Civil engineers & 41 & 6 \\
\hline Product designers and design engineers & 37 & 4 \\
\hline Professional trainers and industry educators & 35 & 2 \\
\hline Developers & 33 & 5 \\
\hline $\begin{array}{l}\text { Applied and field scientists (biologists, } \\
\text { environmental, archaeologists, etc.) }\end{array}$ & 32 & 11 \\
\hline Other engineers & 31 & 2 \\
\hline Professors and teachers & 29 & 12 \\
\hline Power systems and transmission engineers & 22 & 3 \\
\hline Research scientists and research engineers & 21 & 2 \\
\hline Transportation and logistics workers & 20 & 26 \\
\hline Resource assessors and surveyors & 19 & 7 \\
\hline Assembly workers & 18 & 7 \\
\hline Wind technicians & 16 & 35 \\
\hline Construction laborers & 9 & 58 \\
\hline Government regulatory workers & 8 & 6 \\
\hline
\end{tabular}

The figures in Table 1 reflect characteristics of occupations at the companies that responded. This is not meant to reflect companies or occupations in the industry as a whole. 


\subsection{Method: Education and Training Programs}

In addition to the employer surveys, NREL staff conducted primary research on educational and training programs within the United States that focused on wind energy curricula. This research expanded on information that was collected in the 2012 workforce study. NREL researchers identified potential survey participants using an internally maintained list of educational and training programs available in the United States. ${ }^{9}$ NREL circulated the questionnaire to 112 educational and training institutions that provided curricula focused on wind energy (or the renewable energy industry, including wind). Of these, 68 of the institutions completed the questionnaire. Of the 68 institutions, 50 indicated that they offered degrees or certificates in wind or renewable energy in general with some coursework dedicated to wind.

\subsection{Method: Wind Workforce Estimates: New Jobs for One Wind Vision Scenario}

Modeling the needs of the future wind workforce requires two categories for each year: annual and cumulative installed wind capacity. The annual category lists occupations that support new installations and only happen once in the life of a wind plant (such as construction laborers building foundations or roads). For a utility-scale wind farm, this usually means hundreds of jobs during project construction for each wind farm. The cumulative category lists jobs that last for the life of the wind farm and include operations and maintenance (O\&M) (e.g., a wind turbine technician working to fix a gearbox after 10 years of service). For a utility-scale wind farm, approximately five to seven workers are needed to maintain every 100 megawatts for the $\sim 25$ year life of the wind project (Tegen 2016).

The employment estimates in the Wind Vision study were developed using the Wind Jobs and Economic Development Impacts (JEDI) model. This model was parameterized with existing and new nameplate capacity under each scenario along with low and high estimates of goods and services purchased within the United States. This analysis considered new plants, as well as rebuilding of existing wind plants, although the employment analysis did not differentiate these repowered facilities from new construction.

There is more variability in employment growth in occupations related to new installations compared to O\&M as these are dependent on new construction with shorter-term jobs. This research uses one capacity expansion scenario from the DOE Wind Vision (2015) for annual and cumulative wind power installations. ${ }^{10,11}$ BW Research Partners provided baseline 2016 estimates of employment by occupation (DOE 2017). ${ }^{12}$

\subsection{Method: Estimated Number of Graduates Needed by Degree Type}

An optimal workforce ecosystem has students interested in pursuing careers who enroll in educational institutions that offer relevant programs and employers who then hire the graduating

\footnotetext{
${ }^{9}$ https://windexchange.energy.gov/training

${ }^{10}$ The Wind Vision Scenario used in this report is called the Central Study Scenario.

${ }^{11}$ The geographic diversity of potential development in the Central Study Scenario was based on a framework wherein costs are minimized while electricity demand is met. This does not necessarily reflect future development locations and thus where jobs are likely to become available. The scenario was an estimate of potential market growth and, although not perfect, should provide reasonable assumptions of regional market growth.

12 Appendix D contains information about the methodology used to arrive at this estimate.
} 
students. Many of those surveyed reported difficulty hiring qualified candidates while many educational institutions reported courses not filled and graduates not finding jobs. We refer to this mismatch as the "workforce gap": the difference between qualified workers finding employment and employers filling open positions.

Data from this report can be used to show the level of demand for wind industry workers as well as to communicate education and training sources of qualified workers to employers. We performed a close examination of needs by occupation, educational attainment, and geography. The next section details survey responses.

The number of students needed from different degree programs was estimated based on growth in wind occupations and the educational needs for those occupations. The Wind Vision study did not include employment estimates by occupation. The figures in this study assume that the mix of occupations remains fixed and proportional to employment growth. 


\section{Survey Responses}

Common themes emerged from employer surveys. An average of 68\% (more than two-thirds) of wind industry surveyees reported some or great difficulty finding qualified applicants across most occupations, especially scientists and trade workers. Previous assessments show this as well. In A National Skills Assessment of the U.S. Wind Industry in 2012 (Leventhal and Tegen), $67 \%$ of employers reported some or great difficulty finding qualified applicants.

Meanwhile, several educational institutions surveyed reported low enrollment in wind-energy specific programs (others reported record highs), and some institutions noted that some students who complete their programs are not entering the wind industry. Of the 50 institutions that offer wind or renewable energy programs, $46 \%$ indicated that fewer than half of their graduates enter the wind industry.

\section{Representatives from more than two-thirds of the firms surveyed stated that it is difficult to find qualified candidates with a wind energy background.}

\subsection{Employer Experiences: Hiring in the Wind Industry}

The success rate of finding qualified applicants varies across occupations, but employers reported at least some difficulty hiring for two-thirds of all occupations. On average, the majority of employers indicated that they had some difficulty (not great difficulty) finding qualified applicants. The occupation for which employers expressed the most difficulty in finding qualified applicants was scientists (both applied scientists and field scientists), followed by trade workers.

Table 2 shows survey responses by occupation along with bar charts that show the range of desired educational attainment, from high school to a Ph.D. or law degree. This bar chart indicates the number of responses that were selected at the desired education level for a certain occupation. The height of the blue bar indicates the number of hiring managers that prefer this level for a given occupation.

Table 2 also shows the number of employees within occupations that their employers indicated were difficult to fill. This is highest for trade workers, with 813 from our surveys employed in that occupation when their employers cited difficulty hiring them. 
How to Interpret Bars:

Preferred Educational Attainment Level for Occupations
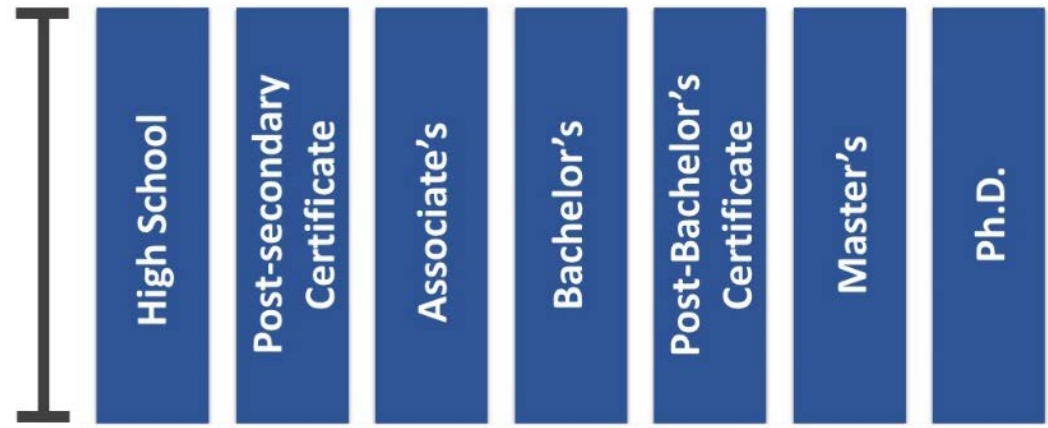

Height of bar indicates number of hiring managers that prefer this level for a given occupation

\section{Educational Attainment (Left to right: High School, Postsecondary Certificate, Associate's, Bachelor's, Post-Bachelor's Certificate, Master's, and Ph.D.)}

Figure 1. How to interpret the Sparklines depicting preferred educational attainment for new hires in Table 2 
Table 2. Level of Difficulty in Finding Qualified Applicants (by Occupation)

\begin{tabular}{|c|c|c|c|c|}
\hline & & $\begin{array}{l}\text { No } \\
\text { Difficulty }\end{array}$ & $\begin{array}{l}\text { Some or Great } \\
\text { Difficulty }\end{array}$ & $\begin{array}{l}\text { Number of } \\
\text { Workers Cited } \\
\text { When Employer } \\
\text { Indicated Difficulty }\end{array}$ \\
\hline $\begin{array}{l}\text { Applied and field scientists (biologists, environmental, } \\
\text { archaeologists, etc.) }\end{array}$ & $-\quad \mathbf{a}-$ & $4 \%$ & $94 \%$ & 333 \\
\hline Trade workers (electricians, welders, etc.) & 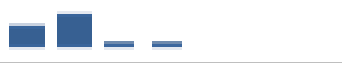 & $6 \%$ & $94 \%$ & 813 \\
\hline Government regulatory workers & 口-ーー & $7 \%$ & $93 \%$ & 41 \\
\hline Resource assessors and surveyors & $--\square---$ & $6 \%$ & $91 \%$ & 119 \\
\hline Attorneys & $---\square$ & $11 \%$ & $89 \%$ & 442 \\
\hline Civil engineers & $--ー-\square$ & $16 \%$ & $84 \%$ & 214 \\
\hline Transportation and logistics workers & a-- - & $19 \%$ & $80 \%$ & 418 \\
\hline Developers & $-\mathbf{a}-\mathbf{a}$ & $15 \%$ & $80 \%$ & 129 \\
\hline Research scientists and engineers & $--\quad-\square$ & $13 \%$ & $79 \%$ & 30 \\
\hline Power systems and transmission engineers & $--\square=-$ & $23 \%$ & $77 \%$ & 58 \\
\hline Other engineers & $---\square-a-$ & $21 \%$ & $77 \%$ & 59 \\
\hline Product designers and design engineers & $--\square--$ & $25 \%$ & $74 \%$ & 103 \\
\hline Assembly workers & $\square--$ & $28 \%$ & $72 \%$ & 89 \\
\hline Programmers and computer scientists & $--\square-ー-$ & $26 \%$ & $70 \%$ & 82 \\
\hline Economists and policy experts & $-\quad--\square-$ & $23 \%$ & $70 \%$ & 56 \\
\hline Electrical and mechanical engineers & $-\square=\square-$ & $31 \%$ & $66 \%$ & 249 \\
\hline
\end{tabular}




\begin{tabular}{|c|c|c|c|c|}
\hline & & $\begin{array}{l}\text { No } \\
\text { Difficulty }\end{array}$ & $\begin{array}{l}\text { Some or Great } \\
\text { Difficulty }\end{array}$ & $\begin{array}{l}\text { Number of } \\
\text { Workers Cited } \\
\text { When Employer } \\
\text { Indicated Difficulty }\end{array}$ \\
\hline Sales and marketing professionals & $---\square--$ & $33 \%$ & $61 \%$ & 199 \\
\hline Professional trainers and industry educators & $-a-\square---$ & $28 \%$ & $53 \%$ & 40 \\
\hline Accountants, bookkeepers, and finance professionals & $---\square-\square$ & $45 \%$ & $50 \%$ & 120 \\
\hline Administrative and clerical workers & $\square=\square \square---$ & $51 \%$ & $46 \%$ & 167 \\
\hline Construction laborers & & $61 \%$ & $39 \%$ & 205 \\
\hline Wind technicians & $\square \square \square-$ & $67 \%$ & $33 \%$ & 182 \\
\hline Professors and teachers & $----\square$ & $60 \%$ & $30 \%$ & 104 \\
\hline Communications and public relations professionals & $---\square--$ & $65 \%$ & $27 \%$ & 29 \\
\hline
\end{tabular}


When wind industry hiring managers or their representatives were asked about the education level they desire from their candidates, a bachelor's degree was the most common response (from half of the respondents). Nearly $30 \%$ of respondents wanted post-graduate education, and $20 \%$ wanted a high school diploma, a post-secondary certificate, or an associate's degree.

Table 3 shows detailed data of preferred educational attainment for new hires. Each row shows the percentage of respondents that indicate the level of education shown in columns. For example, 55\% of employers prefer a bachelor's degree for applied and field scientists and 40\% prefer a master's degree. Each row, then, sums to approximately $100 \%$ (due to rounding).

Table 3. Preferred Educational Attainments for New Hires

\begin{tabular}{|c|c|c|c|c|c|c|c|}
\hline & $\begin{array}{l}\text { High } \\
\text { School } \\
\text { Diploma } \\
\text { or Less }\end{array}$ & $\begin{array}{l}\text { Post- } \\
\text { Secondary } \\
\text { Professional } \\
\text { Certificate }\end{array}$ & $\begin{array}{l}\text { Associate's } \\
\text { Degree }\end{array}$ & $\begin{array}{l}\text { Bachelor's } \\
\text { Degree }\end{array}$ & $\begin{array}{l}\text { Post- } \\
\text { Bachelor's } \\
\text { Professional } \\
\text { Certification }\end{array}$ & $\begin{array}{l}\text { Master's } \\
\text { Degree }\end{array}$ & $\begin{array}{l}\text { Ph.D. or } \\
\text { Professional } \\
\text { Degree }\end{array}$ \\
\hline $\begin{array}{l}\text { Applied and field } \\
\text { scientists } \\
\text { (biologists, } \\
\text { environmental, } \\
\text { archaeologists, } \\
\text { etc.) }\end{array}$ & $0 \%$ & $1 \%$ & $0 \%$ & $55 \%$ & $1 \%$ & $40 \%$ & $3 \%$ \\
\hline $\begin{array}{l}\text { Trade workers } \\
\text { (electricians, } \\
\text { welders, etc.) }\end{array}$ & $37 \%$ & $62 \%$ & $1 \%$ & $0 \%$ & $0 \%$ & $0 \%$ & $0 \%$ \\
\hline $\begin{array}{l}\text { Government } \\
\text { regulatory } \\
\text { workers }\end{array}$ & $0 \%$ & $0 \%$ & $0 \%$ & $55 \%$ & $9 \%$ & $20 \%$ & $16 \%$ \\
\hline $\begin{array}{l}\text { Resource } \\
\text { assessors and } \\
\text { surveyors }\end{array}$ & $0 \%$ & $2 \%$ & $9 \%$ & $86 \%$ & $1 \%$ & $2 \%$ & $1 \%$ \\
\hline Attorneys & $0 \%$ & $0 \%$ & $0 \%$ & $1 \%$ & $6 \%$ & $7 \%$ & $86 \%$ \\
\hline Civil engineers & $0 \%$ & $0 \%$ & $0 \%$ & $21 \%$ & $2 \%$ & $76 \%$ & $0 \%$ \\
\hline $\begin{array}{l}\text { Transportation } \\
\text { and logistics } \\
\text { workers }\end{array}$ & $76 \%$ & $18 \%$ & $1 \%$ & $4 \%$ & $0 \%$ & $0 \%$ & $0 \%$ \\
\hline Developers & $0 \%$ & $0 \%$ & $1 \%$ & $37 \%$ & $18 \%$ & $44 \%$ & $0 \%$ \\
\hline $\begin{array}{l}\text { Research } \\
\text { scientists and } \\
\text { engineers }\end{array}$ & $0 \%$ & $0 \%$ & $3 \%$ & $5 \%$ & $0 \%$ & $26 \%$ & $66 \%$ \\
\hline $\begin{array}{l}\text { Power systems } \\
\text { and } \\
\text { transmission } \\
\text { engineers }\end{array}$ & $0 \%$ & $0 \%$ & $1 \%$ & $7 \%$ & $54 \%$ & $35 \%$ & $3 \%$ \\
\hline Other engineers & $1 \%$ & $1 \%$ & $3 \%$ & $54 \%$ & $6 \%$ & $28 \%$ & $7 \%$ \\
\hline
\end{tabular}




\begin{tabular}{|c|c|c|c|c|c|c|c|}
\hline & $\begin{array}{l}\text { High } \\
\text { School } \\
\text { Diploma } \\
\text { or Less }\end{array}$ & $\begin{array}{l}\text { Post- } \\
\text { Secondary } \\
\text { Professional } \\
\text { Certificate }\end{array}$ & $\begin{array}{l}\text { Associate's } \\
\text { Degree }\end{array}$ & $\begin{array}{l}\text { Bachelor's } \\
\text { Degree }\end{array}$ & $\begin{array}{l}\text { Post- } \\
\text { Bachelor's } \\
\text { Professional } \\
\text { Certification }\end{array}$ & $\begin{array}{l}\text { Master's } \\
\text { Degree }\end{array}$ & $\begin{array}{l}\text { Ph.D. or } \\
\text { Professional } \\
\text { Degree }\end{array}$ \\
\hline $\begin{array}{l}\text { Product } \\
\text { designers and } \\
\text { design } \\
\text { engineers }\end{array}$ & $0 \%$ & $1 \%$ & $2 \%$ & $77 \%$ & $0 \%$ & $10 \%$ & $5 \%$ \\
\hline $\begin{array}{l}\text { Assembly } \\
\text { workers }\end{array}$ & $72 \%$ & $11 \%$ & $15 \%$ & $0 \%$ & $0 \%$ & $0 \%$ & $2 \%$ \\
\hline $\begin{array}{l}\text { Programmers } \\
\text { and computer } \\
\text { scientists }\end{array}$ & $0 \%$ & $2 \%$ & $1 \%$ & $61 \%$ & $4 \%$ & $17 \%$ & $1 \%$ \\
\hline $\begin{array}{l}\text { Economists and } \\
\text { policy experts }\end{array}$ & $0 \%$ & $5 \%$ & $0 \%$ & $13 \%$ & $5 \%$ & $65 \%$ & $10 \%$ \\
\hline $\begin{array}{l}\text { Electrical and } \\
\text { mechanical } \\
\text { engineers }\end{array}$ & $0 \%$ & $0 \%$ & $1 \%$ & $47 \%$ & $24 \%$ & $20 \%$ & $8 \%$ \\
\hline $\begin{array}{l}\text { Sales and } \\
\text { marketing } \\
\text { professionals }\end{array}$ & $4 \%$ & $1 \%$ & $2 \%$ & $79 \%$ & $0 \%$ & $10 \%$ & $0 \%$ \\
\hline $\begin{array}{l}\text { Professional } \\
\text { trainers and } \\
\text { industry } \\
\text { educators }\end{array}$ & $3 \%$ & $21 \%$ & $1 \%$ & $57 \%$ & $5 \%$ & $8 \%$ & $1 \%$ \\
\hline $\begin{array}{l}\text { Accountants, } \\
\text { bookkeepers, } \\
\text { and finance } \\
\text { professionals }\end{array}$ & $1 \%$ & $4 \%$ & $5 \%$ & $57 \%$ & $10 \%$ & $21 \%$ & $0 \%$ \\
\hline $\begin{array}{l}\text { Administrative } \\
\text { and clerical } \\
\text { workers }\end{array}$ & $21 \%$ & $15 \%$ & $26 \%$ & $34 \%$ & $1 \%$ & $1 \%$ & $0 \%$ \\
\hline $\begin{array}{l}\text { Construction } \\
\text { laborers }\end{array}$ & $100 \%$ & $0 \%$ & $0 \%$ & $0 \%$ & $0 \%$ & $0 \%$ & $0 \%$ \\
\hline $\begin{array}{l}\text { Wind } \\
\text { technicians }\end{array}$ & $22 \%$ & $46 \%$ & $30 \%$ & $2 \%$ & $0 \%$ & $0 \%$ & $0 \%$ \\
\hline $\begin{array}{l}\text { Professors and } \\
\text { teachers }\end{array}$ & $0 \%$ & $0 \%$ & $2 \%$ & $1 \%$ & $2 \%$ & $14 \%$ & $81 \%$ \\
\hline $\begin{array}{l}\text { Communications } \\
\text { and public } \\
\text { relations } \\
\text { professionals }\end{array}$ & $1 \%$ & $1 \%$ & $3 \%$ & $86 \%$ & $4 \%$ & $3 \%$ & $0 \%$ \\
\hline
\end{tabular}


Responses shown in Table 3 are for all types of educational attainment, which is not necessarily wind specific. About one-third of employers, however, require or prefer wind energy-specific degrees or certification, while half prefer some type of training or coursework. As shown in Table 4 , these vary across occupations.

To employers, wind energy-specific credentials (instead of occupation-centered credentials) are most important for wind technicians, professional trainers, applied and field scientists, and power systems engineers (Table 4). The type of wind-specific credentials (training or certification) can vary, although the most significant variation is in occupations that do not require the highest levels of wind-specific training or education. These include administrative and clerical workers, resource assessors, attorneys, and assembly workers.

Table 4. Importance of Levels of Required or Preferred Wind Energy-Specific Training and Education

\begin{tabular}{llll}
\hline & $\begin{array}{l}\text { Training (Including } \\
\text { Percentages Are Sum of Required and Preferred }\end{array}$ & $\begin{array}{l}\text { Courses, } \\
\text { Workshops, } \\
\text { Conferences, Etc.) }\end{array}$ & $\begin{array}{l}\text { Professional } \\
\text { Certification }\end{array}$
\end{tabular}

Wind Energy-Specific Occupations and Education

Applied and field scientists (biologists, environmental, archaeologists, etc.)

Professors and teachers

Professional trainers and industry educators

Developers

Construction laborers

Electrical and mechanical engineers

Power systems and transmission engineers

Product designers and design engineers

Wind technicians

Research scientists and engineers

Sales and marketing professionals

Other engineers

Economists and policy experts

Programmers and computer scientists

Trade workers (electricians, welders, etc.)

$95 \%$

$92 \%$

$74 \%$

$73 \%$

$72 \%$

$68 \%$

$64 \%$

$64 \%$

$61 \%$

$53 \%$

$52 \%$

$51 \%$

$48 \%$

$37 \%$

Communications and public relations professionals

Civil engineers

Transportation and logistics workers

Assembly workers

Accountants, bookkeepers, and finance professionals

Administrative and clerical workers

Resource assessors and surveyors

Attorneys

Government regulatory workers
$34 \%$

$31 \%$

$28 \%$

$25 \%$

$21 \%$

$20 \%$

$10 \%$

$10 \%$

$10 \%$

$5 \%$

\begin{tabular}{ll}
$48 \%$ & $17 \%$ \\
\hline $27 \%$ & $25 \%$ \\
$74 \%$ & $59 \%$ \\
$21 \%$ & $46 \%$ \\
$1 \%$ & $0 \%$ \\
$37 \%$ & $38 \%$ \\
$31 \%$ & $50 \%$ \\
$36 \%$ & $23 \%$ \\
$62 \%$ & $92 \%$ \\
$37 \%$ & $18 \%$ \\
$25 \%$ & $20 \%$ \\
$40 \%$ & $15 \%$ \\
$16 \%$ & $10 \%$ \\
$16 \%$ & $18 \%$ \\
$24 \%$ & $14 \%$ \\
$9 \%$ & $9 \%$ \\
$18 \%$ & $9 \%$ \\
$22 \%$ & $0 \%$ \\
$33 \%$ & $20 \%$ \\
$7 \%$ & $7 \%$ \\
\hline $5 \%$ & $7 \%$ \\
$10 \%$ & $2 \%$ \\
$1 \%$ & $1 \%$ \\
$50 \%$ & $0 \%$ \\
\hline
\end{tabular}


Employers indicated that prior work experience, either in wind or in general, is also a priority in evaluating new hires (Table 5). As is the case with educational attainment, this varies by occupation. In Table 5, employers' preferences for types of prior work experience are compared across occupations. This experience can be general or wind-specific.

Survey results show that experience in the wind industry is most important for power and transmission system engineers and research scientists. Experience in general is most important for professional trainers, applied and field scientists, and attorneys. This table shows the hiring manager preferences by occupation for candidates who apply for a job with work experience in their field (e.g., an attorney or a salesperson) as well as preferences for people who have experience in wind energy (e.g., an attorney who has experience with wind energy power purchase agreements or a salesperson who has experience in wind turbine gearbox sales).

\section{For more than half of the occupations considered, hiring managers prefer candidates who have wind energy experience in addition to general experience (see Table 5). Occupational experience in the wind industry is most important when hiring:}

- Wind technicians

- Power systems and transmission engineers

- Wind energy developers. 
Table 5. Work Experience: Importance of Occupational Experience and Wind-Specific Experience

\begin{tabular}{|c|c|c|}
\hline & $\begin{array}{l}\text { Prefer Experience in the } \\
\text { Wind Industry }\end{array}$ & $\begin{array}{l}\text { Prefer Experience } \\
\text { in General }\end{array}$ \\
\hline & Wind Experience & General Experience \\
\hline Power systems and transmission engineers & $97 \%$ & $89 \%$ \\
\hline $\begin{array}{l}\text { Applied and field scientists (biologists, } \\
\text { environmental, archaeologists, etc.) }\end{array}$ & $94 \%$ & $99 \%$ \\
\hline Professors and teachers & $92 \%$ & $96 \%$ \\
\hline Construction laborers & $91 \%$ & $96 \%$ \\
\hline Developers & $87 \%$ & $95 \%$ \\
\hline Trade workers (electricians, welders, etc.) & $77 \%$ & $94 \%$ \\
\hline Professional trainers and industry educators & $76 \%$ & $100 \%$ \\
\hline Electrical and mechanical engineers & $71 \%$ & $77 \%$ \\
\hline Other engineers & $71 \%$ & $83 \%$ \\
\hline Sales and marketing professionals & $68 \%$ & $85 \%$ \\
\hline Economists and policy experts & $65 \%$ & $86 \%$ \\
\hline Wind technicians & $64 \%$ & $64 \%$ \\
\hline Communications and public relations professionals & $64 \%$ & $77 \%$ \\
\hline Research scientists and engineers & $50 \%$ & $63 \%$ \\
\hline Product designers and design engineers & $50 \%$ & $67 \%$ \\
\hline Accountants, bookkeepers, and finance professionals & $44 \%$ & $58 \%$ \\
\hline Transportation and logistics workers & $38 \%$ & $43 \%$ \\
\hline Assembly workers & $36 \%$ & $71 \%$ \\
\hline Civil engineers & $35 \%$ & $40 \%$ \\
\hline Government regulatory workers & $30 \%$ & $55 \%$ \\
\hline Administrative and clerical workers & $23 \%$ & $64 \%$ \\
\hline Programmers and computer scientists & $22 \%$ & $82 \%$ \\
\hline Resource assessors and surveyors & $17 \%$ & $19 \%$ \\
\hline Attorneys & $15 \%$ & $99 \%$ \\
\hline
\end{tabular}




\subsection{Workforce Demographics: Women, Minorities, and Veterans in the Wind Industry}

Survey results showed that veterans are more represented in the wind industry than in the population as a whole. They make up approximately $7.5 \%$ of the U.S. population and $11 \%$ of the wind workforce (United States Department of Veterans Affairs 2017). Racial and ethnic minorities and women are less represented in the wind workforce than in the population as a whole. Racial and ethnic minorities make up approximately $39 \%$ of the U.S. population and $31 \%$ of the wind workforce (United States Census Bureau 2018). ${ }^{13}$ Women make up only $25 \%$ of the wind energy workforce.

Table 6 shows percentages of women and racial and ethnic minorities, as well as U.S. military veterans in the wind labor force by occupation. Women are most heavily represented in administrative, accounting, and communications occupations. Minorities are most represented in the construction, wind technician, and civil engineer categories. Construction, wind technician, and professional trainer occupations have the highest concentration of veterans.

\footnotetext{
${ }^{13}$ Racial and ethnic minorities are defined as anyone who is non-white and non-Latino.
} 
Table 6. Percentage of Women, Ethnic Minorities, and Veterans in the U.S. Wind Energy Workforce

\begin{tabular}{|c|c|c|c|}
\hline & $\begin{array}{l}\text { Percent } \\
\text { Women }\end{array}$ & $\begin{array}{l}\text { Percent Racial } \\
\text { and Ethnic } \\
\text { Minorities }\end{array}$ & $\begin{array}{l}\text { Percent U.S. } \\
\text { Veterans }\end{array}$ \\
\hline Administrative and clerical workers & $80 \%$ & $26 \%$ & $2 \%$ \\
\hline $\begin{array}{l}\text { Accountants, bookkeepers, and financial } \\
\text { professionals }\end{array}$ & $61 \%$ & $27 \%$ & $2 \%$ \\
\hline Communications and public relations professionals & $51 \%$ & $16 \%$ & $4 \%$ \\
\hline Government regulatory workers & $50 \%$ & $18 \%$ & $2 \%$ \\
\hline $\begin{array}{l}\text { Applied and field scientists (biologists, } \\
\text { environmental, archaeologists, etc.) }\end{array}$ & $43 \%$ & $8 \%$ & $4 \%$ \\
\hline Civil engineers & $40 \%$ & $42 \%$ & $8 \%$ \\
\hline Economists and policy experts & $33 \%$ & $13 \%$ & $4 \%$ \\
\hline Developers & $25 \%$ & $25 \%$ & $5 \%$ \\
\hline Sales and marketing professionals & $24 \%$ & $14 \%$ & $5 \%$ \\
\hline Programmers and computer scientists & $21 \%$ & $21 \%$ & $11 \%$ \\
\hline Professors and teachers & $17 \%$ & $8 \%$ & $4 \%$ \\
\hline Assembly workers & $15 \%$ & $34 \%$ & $7 \%$ \\
\hline Other engineers & $14 \%$ & $14 \%$ & $9 \%$ \\
\hline Research scientists and engineers & $13 \%$ & $18 \%$ & $5 \%$ \\
\hline Resource assessors and surveyors & $13 \%$ & $33 \%$ & $21 \%$ \\
\hline Product designers and design engineers & $13 \%$ & $20 \%$ & $15 \%$ \\
\hline Professional trainers and industry educators & $12 \%$ & $16 \%$ & $24 \%$ \\
\hline Transportation and logistics workers & $11 \%$ & $36 \%$ & $7 \%$ \\
\hline Electrical and mechanical engineers & $10 \%$ & $16 \%$ & $6 \%$ \\
\hline Power systems and transmission engineers & $9 \%$ & $16 \%$ & $12 \%$ \\
\hline Attorneys & $8 \%$ & $3 \%$ & $1 \%$ \\
\hline Trade workers (electricians, welders, etc.) & $6 \%$ & $20 \%$ & $11 \%$ \\
\hline Construction laborers & $5 \%$ & $57 \%$ & $34 \%$ \\
\hline Wind technicians & $1 \%$ & $50 \%$ & $32 \%$ \\
\hline
\end{tabular}




\subsection{International Hiring}

One-quarter of wind energy firms considered hiring applicants with non-U.S.-based education or experience for jobs in the United States (Figure 2). Applicants from many countries were considered, with Germany and India mentioned most often. Four out of the five most common source countries for non-U.S. applicants are located in Europe.

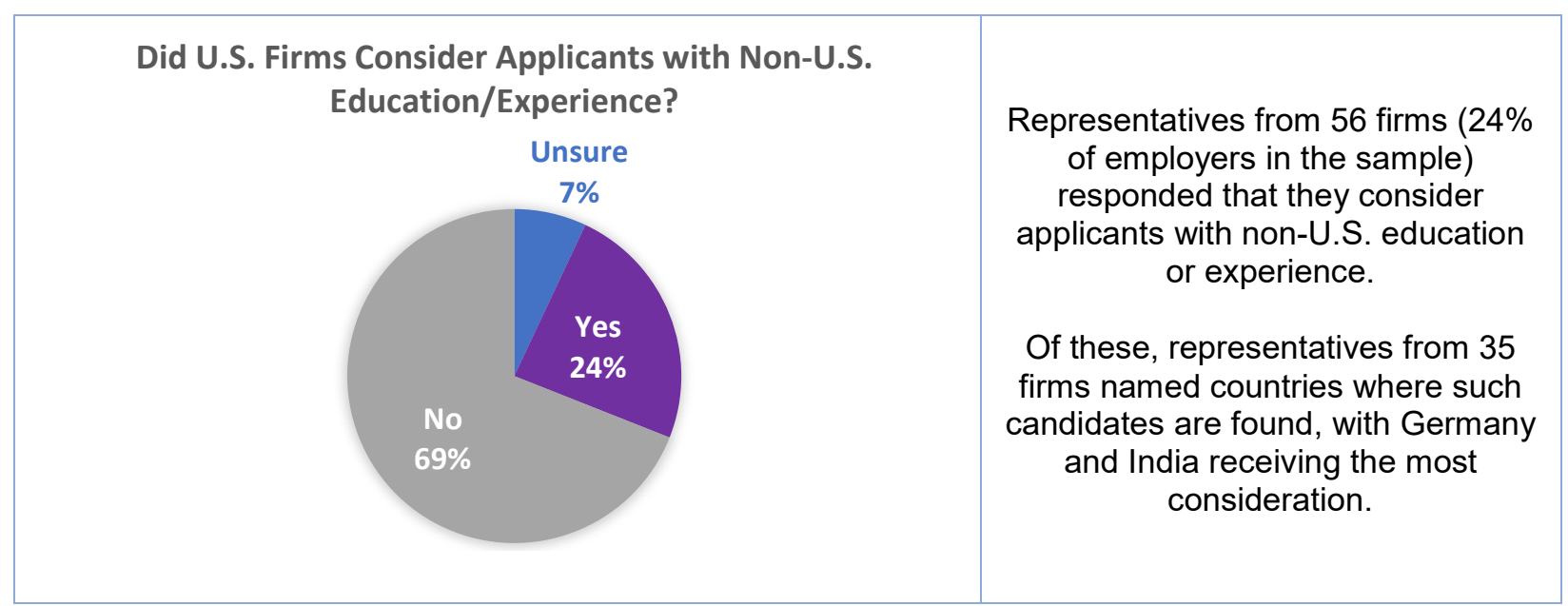

Figure 2. Consideration of non-U.S. applicants by U.S. firms and the countries of origin identified

Wind energy firms that hired workers from abroad viewed U.S. applicants as having less wind energy-specific education and training relative to their international counterparts. They also rated applicants with U.S. education or experience slightly lower on problem solving and critical thinking skills and rated them as having less wind-related experience.

Table 7. Employers' Perceptions of U.S. Applicants Compared to Similarly Educated and Experienced International Applicants

\begin{tabular}{llll}
\hline & $\begin{array}{l}\text { U.S. Applicant } \\
\text { Rated Better }\end{array}$ & $\begin{array}{ll}\text { Same } \\
\text { Problem solving and critical thinking skills }\end{array}$ & $\begin{array}{l}\text { U.S. Applicant } \\
\text { Rated Worse }\end{array}$ \\
\hline Wind-related experience & $13 \%$ & $63 \%$ & $23 \%$ \\
Education and training specific to the wind industry & $19 \%$ & $54 \%$ & $27 \%$ \\
Work ethic & $13 \%$ & $47 \%$ & $36 \%$ \\
\hline
\end{tabular}




\subsection{Education and Training Programs}

The 49 institutions offered 73 degree or certification programs. ${ }^{14}$ Of these, 34 had a windspecific program and 39 had a renewable energy-specific program with a wind component. Among institutions surveyed, most of these degree or certification programs were associate's or post-secondary degrees. The associate's and post-secondary degrees were more likely to be focused exclusively on wind energy than the bachelor's or higher degrees due in part to the wind technician category.

These surveys only asked about training and degree programs, as these are what the institutions offer. They did not ask about occupations, as these are chosen by graduates and may change over time. Table 3 shows employers' desired level of training or educational attainment by occupation, such as mechanical engineers, but it does not perfectly match up with questions answered by educational institutions.

Educational program surveys did not include "in-house," company-based training programs such as the ones offered by large companies like Vestas and GE. The report also did not attempt a systematic assessment of high school or other vocational programs that may be more applicable for entry-level positions that do not require advanced degrees.

Table 8 shows the distribution of programs across degree types, as well as how many people graduated on average from each type of program. The top half of the table includes the number of programs without graduates in 2016.

While there were only seven bachelor's degree programs identified in the surveys, the average graduating class was 28 students, more than graduating classes for the other degree levels. All the bachelor's degree programs had at least one graduate in 2016, while seven of the 26 associate's degree programs did not have graduates in 2016.

\footnotetext{
${ }^{14}$ For a list of the wind energy educational programs currently known to the National Renewable Energy Laboratory, please see https://windexchange.energy.gov/training for a link to each institution with a brief program description.
} 


\begin{tabular}{|c|c|c|c|c|c|c|c|c|c|c|}
\hline & $\begin{array}{l}\text { Wind- } \\
\text { Specific } \\
\text { Program }\end{array}$ & $\begin{array}{l}\text { Renewable } \\
\text { Program } \\
\text { with Wind }\end{array}$ & $\begin{array}{l}\text { Post- } \\
\text { Secondary } \\
\text { Certificate }\end{array}$ & $\begin{array}{l}\text { Associate's } \\
\text { Degree }\end{array}$ & $\begin{array}{l}\text { Bachelor's } \\
\text { Degree }\end{array}$ & $\begin{array}{l}\text { Post- } \\
\text { Bachelor's } \\
\text { Certificate }\end{array}$ & $\begin{array}{l}\text { Master's } \\
\text { and } \\
\text { Above }\end{array}$ & $\begin{array}{l}\text { Aggregate } \\
\text { of } \\
\text { Associate's } \\
\text { and Lower } \\
\text { Degrees }\end{array}$ & $\begin{array}{l}\text { Aggregate } \\
\text { of } \\
\text { Bachelor's } \\
\text { and } \\
\text { Higher } \\
\text { Degrees }\end{array}$ & Total \\
\hline $\begin{array}{l}\text { Number of } \\
\text { certificate or } \\
\text { degree programs }\end{array}$ & 34 & 39 & 21 & 26 & 7 & 9 & 10 & 47 & 26 & 73 \\
\hline $\begin{array}{l}\text { Programs with } \\
\text { zero graduates in } \\
2016\end{array}$ & 7 & 6 & 3 & 7 & 0 & 2 & 1 & 10 & 3 & 13 \\
\hline \multicolumn{11}{|c|}{ Programs with at least one graduate in 2016} \\
\hline $\begin{array}{l}\text { Number of } \\
\text { certificate or } \\
\text { degree programs }\end{array}$ & 27 & 33 & 18 & 19 & 7 & 7 & 9 & 37 & 23 & 60 \\
\hline $\begin{array}{l}\text { Average number } \\
\text { of graduates per } \\
\text { program in } 2016\end{array}$ & 9 & 14 & 14 & 7 & 28 & 11 & 7 & 10 & 14 & 12 \\
\hline
\end{tabular}


The numbers of graduates could likely be increased if more students enrolled, as most institutions contacted reported the ability to increase size without allocating additional resources. ${ }^{15}$ More than $90 \%$ of programs offering post-secondary or associate's degrees reported being able to increase size without additional resources, and more than $80 \%$ of programs offering bachelor's degrees and higher reported the ability to expand. This amounts to a potential $70 \%$ increase in graduates annually at 1- and 2-year degree institutions and more than a $60 \%$ increase in graduates earning a 4-year degree or higher if students were willing to attend the programs that had expanded (which is not a given).

Table 9. Increasing the Number of Graduates without Additional Resources

\begin{tabular}{|c|c|c|}
\hline & $\begin{array}{l}\text { 1- to } 2 \text {-Year } \\
\text { Degrees and } \\
\text { Certificates }\end{array}$ & $\begin{array}{l}\text { Bachelor's } \\
\text { Degrees and } \\
\text { Higher }\end{array}$ \\
\hline \multicolumn{3}{|c|}{ Would it be possible to have more graduates without increasing staff or classroom space? } \\
\hline Yes & $92 \%$ & $83 \%$ \\
\hline No & $8 \%$ & $17 \%$ \\
\hline \multicolumn{3}{|c|}{$\begin{array}{l}\text { How much could you increase enrollment in each of these degree and certificate programs } \\
\text { without dedicating additional resources such as staff hours or classroom space? }\end{array}$} \\
\hline $100 \%$ increase (double enrollment) & $61 \%$ & $60 \%$ \\
\hline $50 \%$ increase & $27 \%$ & $20 \%$ \\
\hline $25 \%$ increase & $9 \%$ & $13 \%$ \\
\hline $10 \%$ increase & $0 \%$ & $0 \%$ \\
\hline $5 \%$ increase & $3 \%$ & $7 \%$ \\
\hline Increase in enrollment weighted by survey responses & $77 \%$ & $74 \%$ \\
\hline $\begin{array}{l}\text { Estimated potential increase in graduates without } \\
\text { requiring additional space or staff (\% Possible * \% } \\
\text { Increase) }\end{array}$ & $70 \%$ & $61 \%$ \\
\hline
\end{tabular}

The average number of graduates from 1- and 2-year institutions in the wind or renewablespecific programs was 10 in $2016 .{ }^{16}$ A $70 \%$ increase from these 10 graduates, as shown in Table 9, would produce 17 graduates annually. Similarly, a 61\% increase from the 14 average annual graduates from 4-year or higher programs would produce 23 graduates annually. The survey responses that they could increase training or education without straining resources such as staff, classroom, space, and other costs shows that the wind workforce could theoretically be increased without additional education programs.

\footnotetext{
15 The survey asked two questions about resources: "Please consider the number of graduates relative to class size capacity for each degree or certificate your institution awards. We are trying to determine whether these programs are running at, or below capacity. Would it be possible to have more graduates without increasing staff or classroom space?" and "How much could you increase enrollment in each of these degree and certificate programs without dedicating additional resources such as staff hours or classroom space?"

16 This refers to graduates from 1- and 2-year institutions with at least one graduate in 2016 from the surveys performed for this report.
} 
Increasing programs without additional resources assumes, however, that students would want to attend these programs and that they could. Barriers such as expense, ability to be enrolled, location, or program desirability could impact the feasibility of this expansion. We know that some wind energy courses at universities are over-subscribed while programs at other institutions are closing due to lack of enrollment.

Each institution also noted the approximate percentage of graduates from their wind energy programs who entered the wind energy industry after graduating (Table 10). The most common response was "only a small portion (less than $20 \%$ )." More than $70 \%$ of programs that award 2year degrees or certificates and 74\% of programs that offer bachelor's degrees and higher reported that less than half of their graduates enter the wind workforce.

\section{More than two-thirds of the students who attend wind energy education and training programs do not enter the wind industry.}

Table 10. Percentage of Graduates Entering Wind Energy

For each type of degree and certificate that your institution awards, what percentage of the graduates actually enter the wind energy industry?

\begin{tabular}{llll}
\hline & $\begin{array}{l}\text { 2-Year Degrees or } \\
\text { Certificates }\end{array}$ & $\begin{array}{l}\text { Bachelor's } \\
\text { Degrees and } \\
\text { Higher }\end{array}$ & Total \\
\hline $\begin{array}{l}\text { (n = number of institutions responding for } \\
\text { each degree type) }\end{array}$ & $(34)$ & $(18)$ & $(52)^{18}$ \\
\hline Almost all of them (90\% or more) & $6 \%$ & $6 \%$ & $6 \%$ \\
\hline The majority (61\%-89\%) & $24 \%$ & $11 \%$ & $19 \%$ \\
\hline About half (40\%-60\%) & $18 \%$ & $11 \%$ & $15 \%$ \\
\hline Less than half (20\%-39\%) & $12 \%$ & $22 \%$ & $15 \%$ \\
\hline Only a small portion (less than $20 \%)$ & $41 \%$ & $50 \%$ & $44 \%$ \\
\hline Total \% Entering the Industry & $\mathbf{3 0 \%}$ & $\mathbf{2 0 \%}$ & \\
\hline
\end{tabular}

${ }^{17}$ Totals appear to sum to $101 \%$ due to rounding

18 This is greater than the number of respondents because some institutions have more than one wind program. 


\section{The Workforce Gap}

The majority of respondents from wind companies surveyed for this study reported difficulty hiring qualified candidates, and representatives from education institutions reported graduates not having jobs once they graduated or not entering the wind industry. Meanwhile, survey respondents from the wind energy programs reported that they could also increase enrollment and graduates without adding resources. All of this took place during years (2016-2017) in which wind technician was the fastest growing occupation in America. This disconnect is referred to as the "workforce gap."

We identify several potential reasons for the workforce gap. Figure 3 shows survey responses, such as that the primary reason students chose not to enter the wind industry is that they found "better opportunities" elsewhere. It is difficult to determine what "better" means, as it could be salary, upward mobility, or other factors. Moreover, responses did not indicate what "other industries" students may be entering - this could include other energy industries or industries outside of the energy workforce. It could also be the location of wind energy jobs, frequently indicated in the "other" jobs response. The desire for students to continue their education also emerged as a barrier to entrance in the wind workforce.

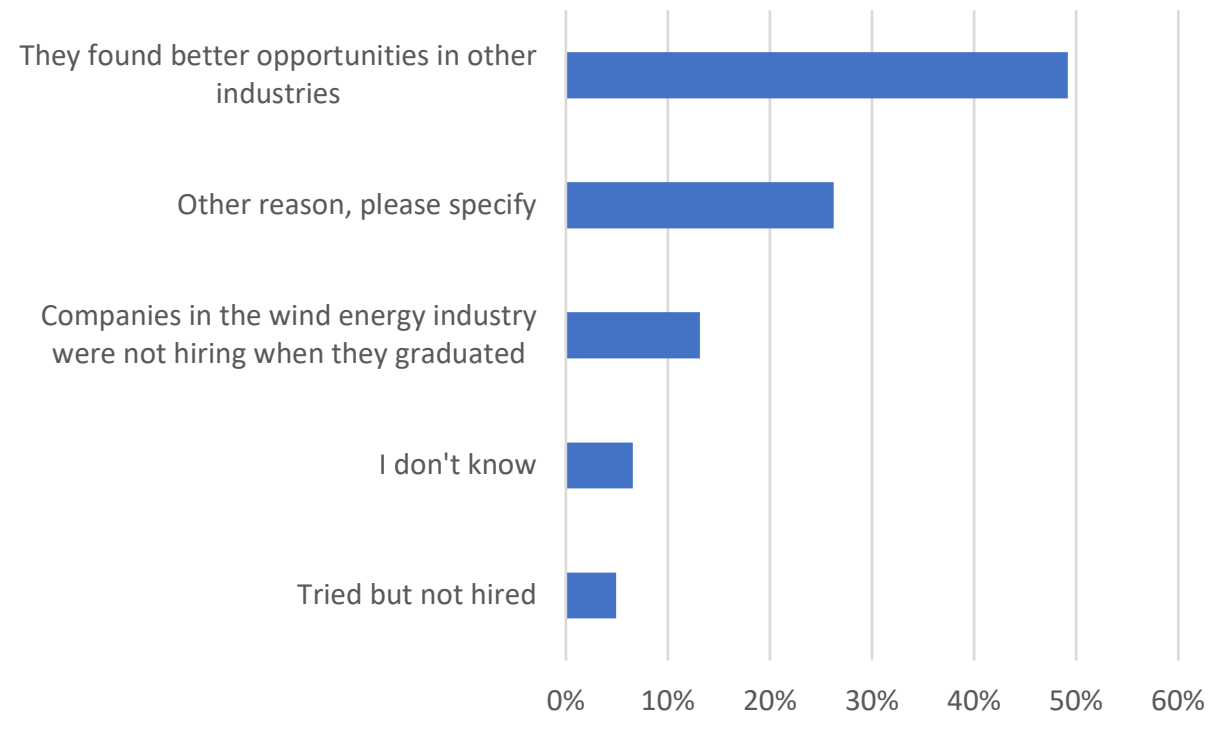

Common Other Reasons: \#1 Geography \#2 Continued education

Figure 3. Reasons why graduates did not enter wind industry ${ }^{19}$

Educational attainment may also play a role in whether a graduate finds a job in the wind industry. Figure 4 shows the distribution of training and degree types among programs that indicated that less than $50 \%$ of their qualified graduates did not enter the wind industry. ${ }^{20}$ These percentages hover around $60 \%$ for all programs except for the students with the highest levels of

\footnotetext{
${ }^{19}$ It is important to note that these reasons are being provided by educators or administrators, not graduates. Conducting research among graduates who were qualified but did not enter the wind energy industry would provide an interesting additional perspective.

${ }^{20}$ Figures are weighted by the number of degree programs in each category.
} 
educational attainment in the master's, Ph.D., and law degree category where nearly $90 \%$ of programs indicated that their graduates do not enter the wind industry.

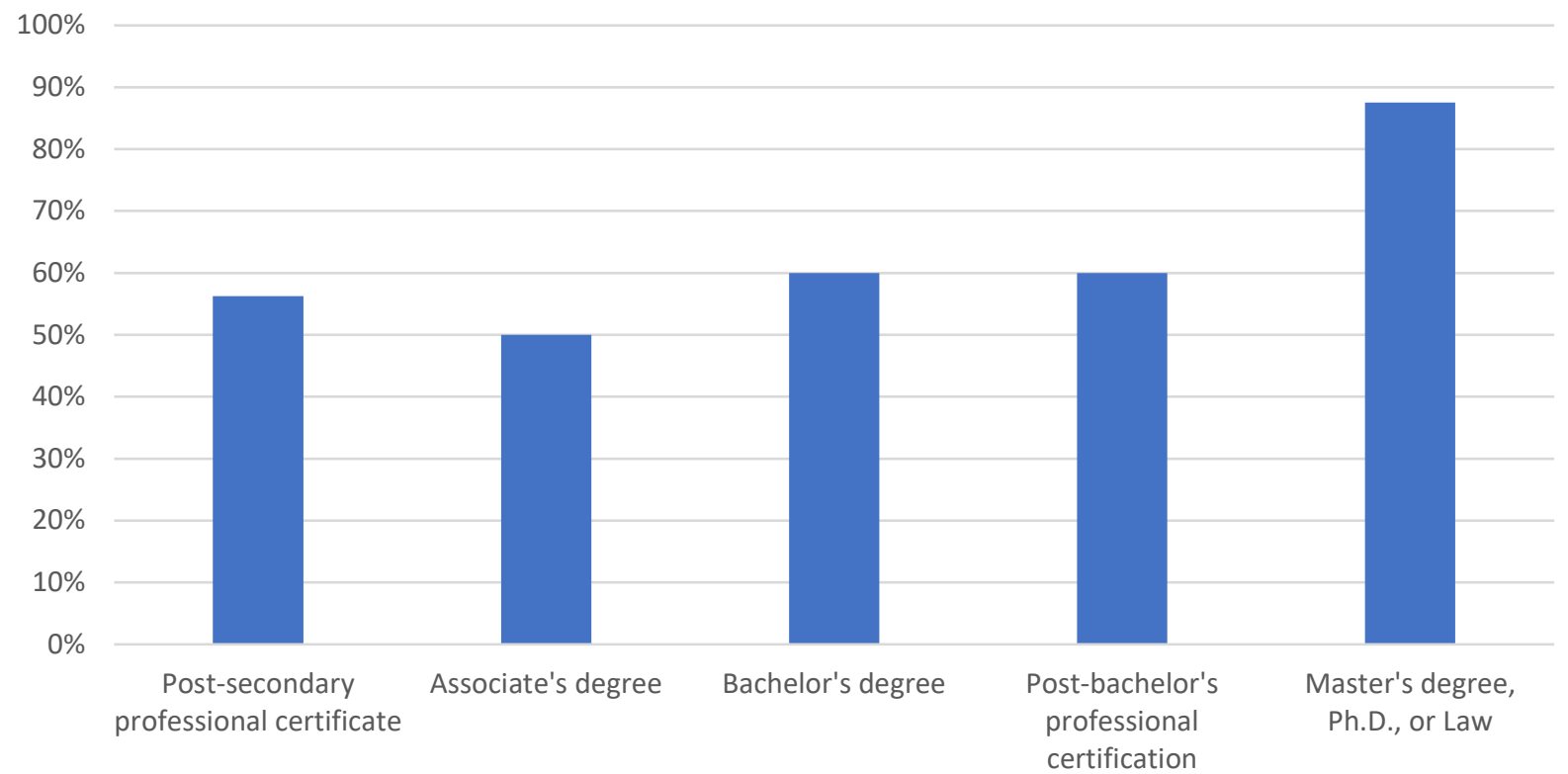

Figure 4. Percentage of types of degree programs in which fewer than half of students enter the wind industry

Another explanation for graduates not entering the wind industry is a reported lack of resources and support at educational institutions. Less than $10 \%$ of education and training institution respondents claimed to "definitely" have the resources and support they need to place graduates into appropriate roles in the wind energy industry. Respondents from more than $20 \%$ of 4 -year colleges and universities cited "not at all" in regard to whether they possessed enough resources. Increases in these resources could help get qualified workers into the domestic wind workforce, thereby decreasing the workforce gap. 


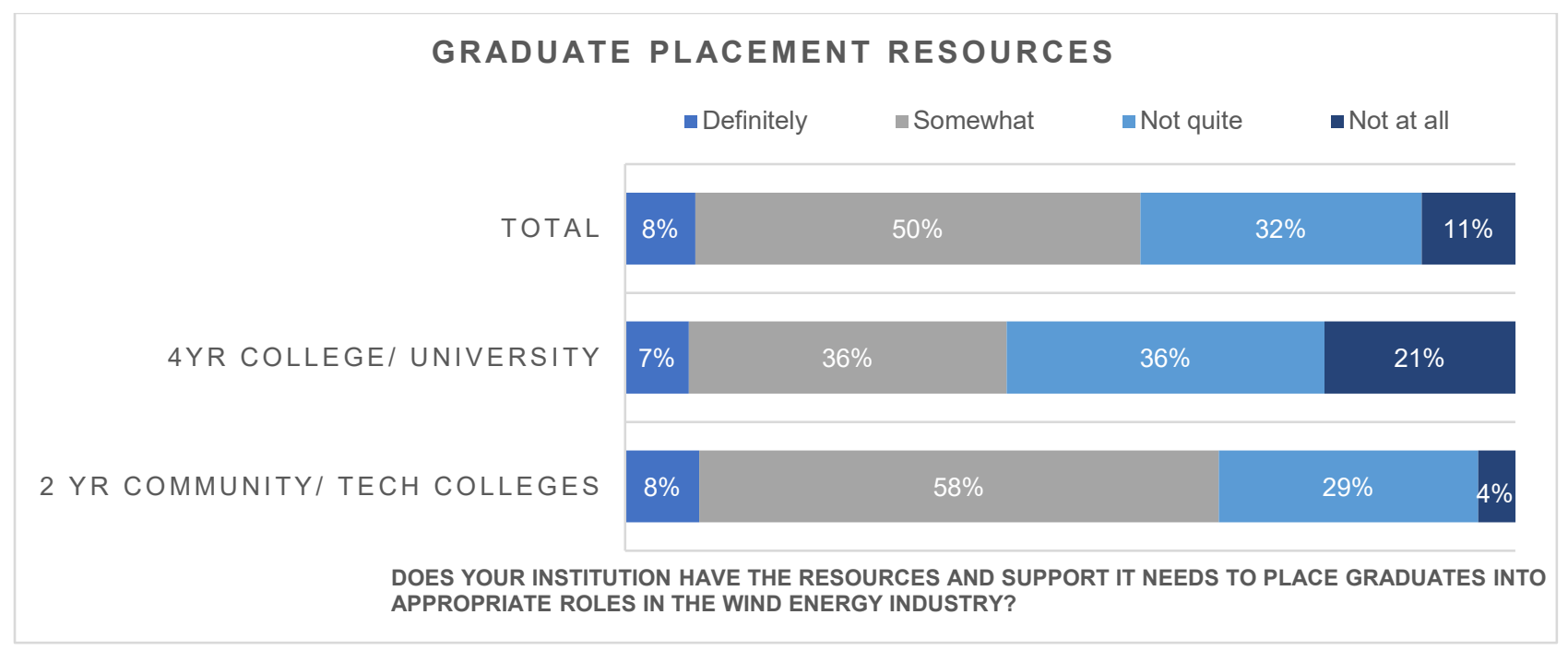

\section{Figure 5. Graduate placement resources}

The reasons institutions lack support are varied, as are whether they expect support to come from their institution or the wind industry. A sampling of reasons educators and administrators chose "not quite" or "not at all" for whether their institution has the resources and support it needs to place graduates into the wind industry include:

- "Our wind certificate is really just getting off the ground, and the college has not put much effort into marketing or job placement."

- "I'm the only faculty member and do what I can to assist placement."

- "These companies don't recruit at [institution name] in the same way that the traditional industries do."

- "There are few wind companies in our state (largely due to stalling of wind projects from state policy several years ago), and therefore there are few companies actively recruiting students at our university."

Respondents at most institutions said they at least "somewhat" had the necessary resources to recruit students, but few stated that they "definitely" had these resources. 


\section{The Future of the U.S. Wind Workforce}

Potential growth of the wind industry will require more workers. If the industry progresses in line with the DOE Wind Vision scenario-one potential path for expansion-more education and training programs will be needed. Growth of this workforce requires students to recognize potential employment opportunities and educational institutions to recognize demand for workers from industry, and therefore demand for programs. Although not the focus of this report, to ensure workers are being prepared to address the needs of the modern wind industry, close collaboration between academic institutions and the wind industry would be needed to ensure workers are being prepared to address the needs of the modern wind industry. It is important to note that some companies do their own "in-house" training, as well as apprenticeships and internships, that were not captured in the scope of this research.

\subsection{Estimated Workforce Demand}

The DOE Wind Vision (2015) provides a potential scenario for wind capacity expansion and associated jobs. Figure 6 displays the percent of total electricity consumption met by wind generation under the Wind Vision Study Central Scenario. Workforce needs for the bourgeoning offshore wind industry, and to a lesser degree the distributed wind industry, would expand the needs as described in this section.

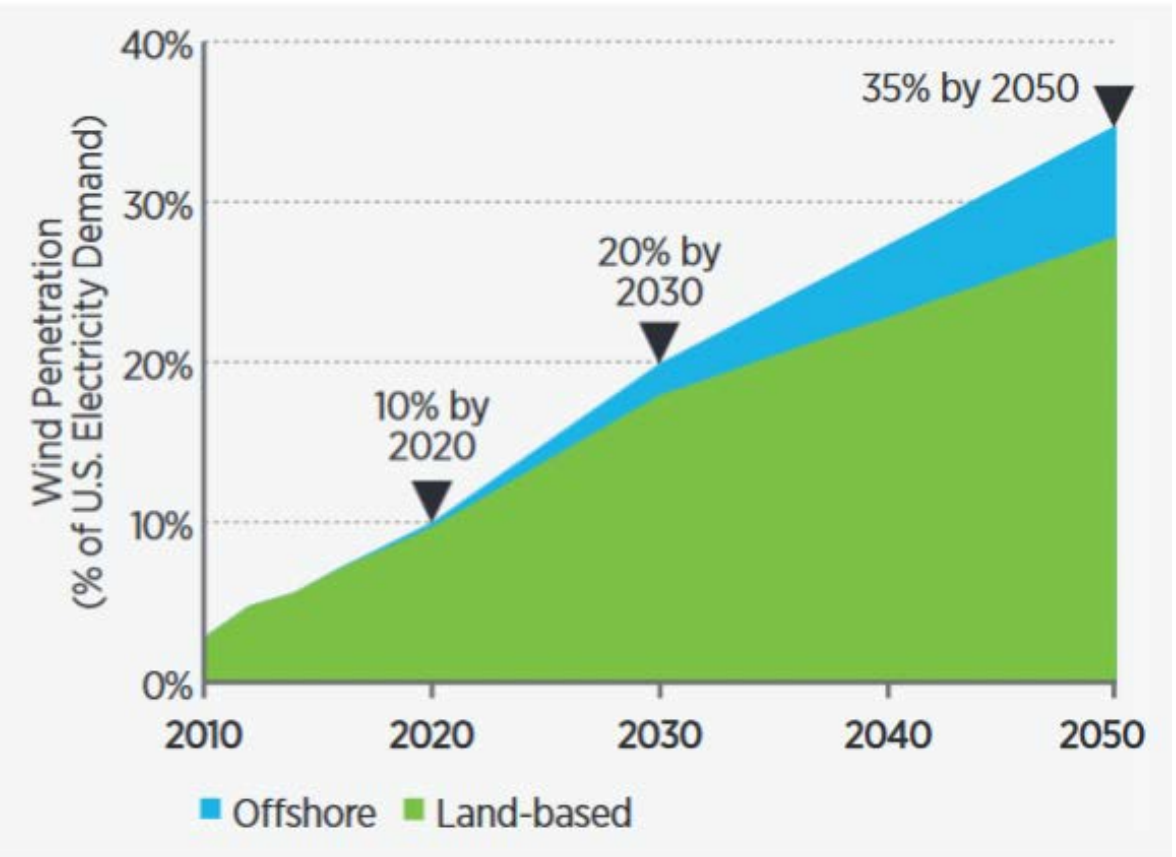

Figure 6. The Wind Vision Study Central Scenario

The occupations that may be needed in the future are related to both the O\&M and the development of new facilities. O\&M jobs change relative to cumulative existing capacity that is in operation, which in the Wind Vision scenario continues to increase through 2050. Employment related to new development and to repowering includes manufacturing and construction, which 
vary with annual installations. Table 11 provides an assessment of how the different occupations previously introduced are dispersed between project development and O\&M.

Table 11. Percent of Workforce Occupations Based on Wind Market Segment

\begin{tabular}{|c|c|c|}
\hline$\geq 90 \%$ Construction/ $\leq 10 \%$ O\&M & $11 \%-50 \%$ in $\mathrm{O} \& \mathrm{M}$ or Construction & $\geq 90 \%$ O\&M$/ \leq 10 \%$ Construction \\
\hline Assembly workers & $\begin{array}{l}\text { Applied and field scientists } \\
\text { (biologists, environmental, } \\
\text { archeologists, etc.) }\end{array}$ & Wind technicians \\
\hline Construction laborers & $\begin{array}{l}\text { Power systems and transmission } \\
\text { engineers }\end{array}$ & \\
\hline Developers & Government regulatory workers & \\
\hline Civil engineers & $\begin{array}{l}\text { Research scientists and research } \\
\text { engineers }\end{array}$ & \\
\hline Electrical and mechanical engineers & $\begin{array}{l}\text { Accountants, bookkeepers, and } \\
\text { finance professionals }\end{array}$ & \\
\hline Resource assessors and surveyors & Attorneys & \\
\hline $\begin{array}{l}\text { Programmers and computer } \\
\text { scientists }\end{array}$ & Professors and teachers & \\
\hline $\begin{array}{l}\text { Communications and public } \\
\text { relations professionals }\end{array}$ & Transportation and logistics workers & \\
\hline Other engineers & Administrative and clerical workers & \\
\hline Sales and marketing professionals & Economists and policy experts & \\
\hline \multirow[t]{2}{*}{$\begin{array}{l}\text { Trade workers (electricians, } \\
\text { welders, etc.) }\end{array}$} & $\begin{array}{l}\text { Product designers and design } \\
\text { engineers }\end{array}$ & \\
\hline & $\begin{array}{l}\text { Professional trainers and industry } \\
\text { educators }\end{array}$ & \\
\hline
\end{tabular}

In addition to figuring in market growth, these employment estimates of potential future job needs in this report assume a $1 \%$ growth rate in annual worker productivity, roughly in line with the annual average change in labor productivity from 2006 to 2016 (BLSb 2018). ${ }^{21}$ Workers per unit of capacity, therefore, will likely change over time. This results in a $40 \%$ productivity gain per worker through 2050.

In addition to accounting for productivity increases, the estimates in this report include a 5\% attrition rate, similar to the attrition rate used in Leventhal and Tegen (2013) although slightly more conservative. Attrition includes those retiring from the workforce, those leaving the wind energy sector to pursue careers in other industries, and mortality. Attrition increases the number of new hires that are needed.

Figure 7 shows the cumulative capacity $(\mathrm{GW})$ installed in the Wind Vision as well as associated O\&M employment (gross, full-time equivalent jobs). These estimates show that the O\&M wind

${ }^{21}$ The annual average change from 2006 to 2016 was $1.2 \%$, although there has been quite a bit of year-over-year variability. The $1 \%$ estimate is rounded to reflect uncertainty. 
workforce would grow from about 23,000 in 2016 to 67,000 in 2050 if Wind Vision deployment levels were achieved.

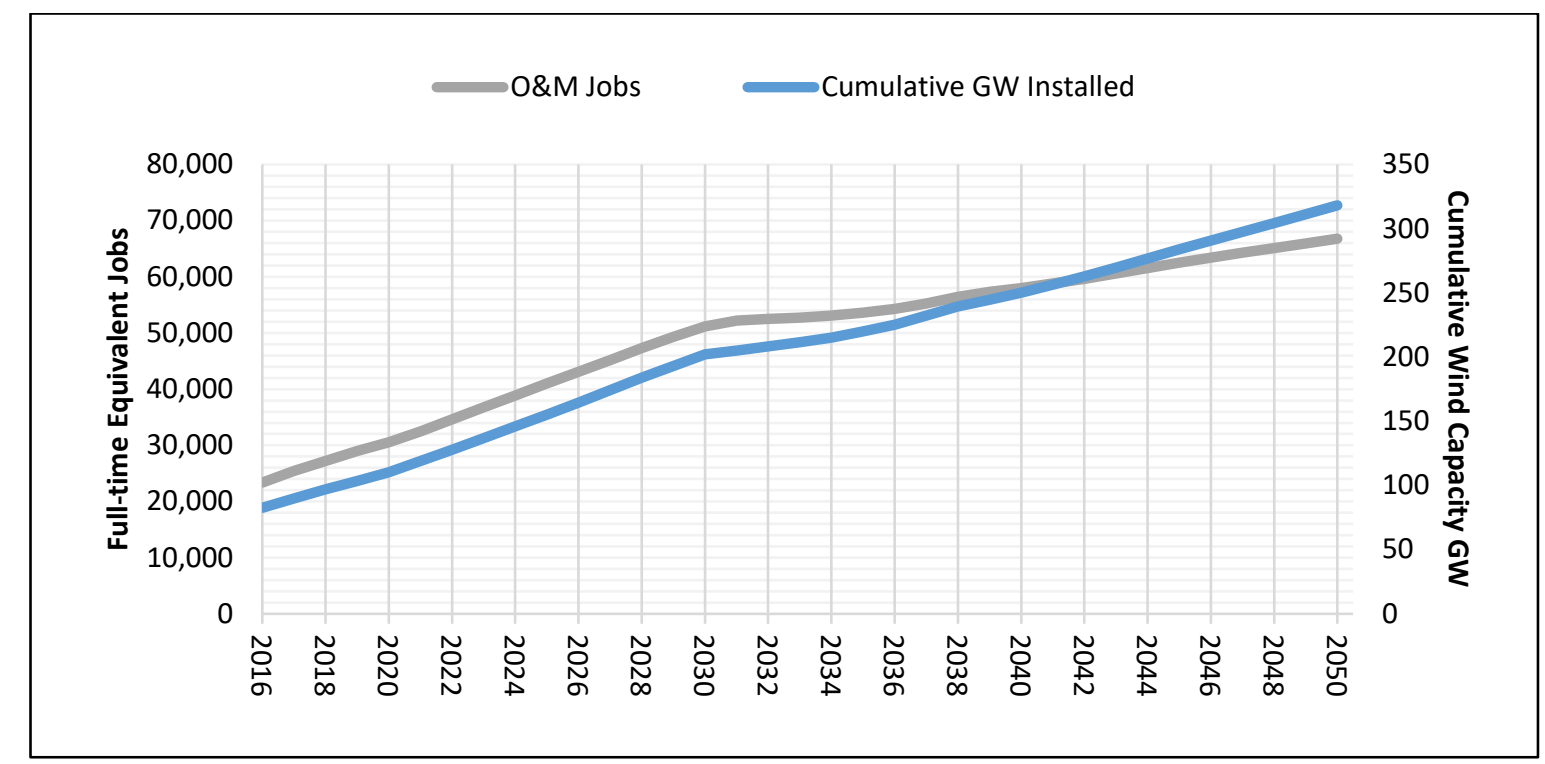

Figure 7. Land-based wind energy workforce (O\&M jobs) that would be supported by the Wind Vision Central Study Scenario

Wind capacity installed annually includes completely new and rebuilt wind sites, as well as repowering efforts. Figure 7 shows the new and rebuilt/repowered wind installations on the right axis along with the gross, full-time equivalent jobs supported by the annual installations on the left axis. As rebuilding, or repowering, replaces available capacity, it may not increase cumulative installed gigawatts of wind because existing turbine capacity could be replaced with the same capacity from newer (and likely fewer) turbines.

The wind workforce focused on installation is expected to vary year to year, as does annual capacity of wind installed. The low of 62,000 workers occurs in 2020 and generally follows an upward trajectory through 2037, when the maximum is reached at about 114,000 workers (Figure 9). ${ }^{22}$ While the amount of annual capacity installed drops off in the years immediately following this peak, it rebounds in the final decade (Figure 7).

\footnotetext{
${ }^{22}$ Estimates in the Wind Vision study use the NREL Jobs and Economic Development Impacts (JEDI) wind models. Appendix I of Wind Vision (2015) contains detailed information about the methodology used to produce these estimates.
} 


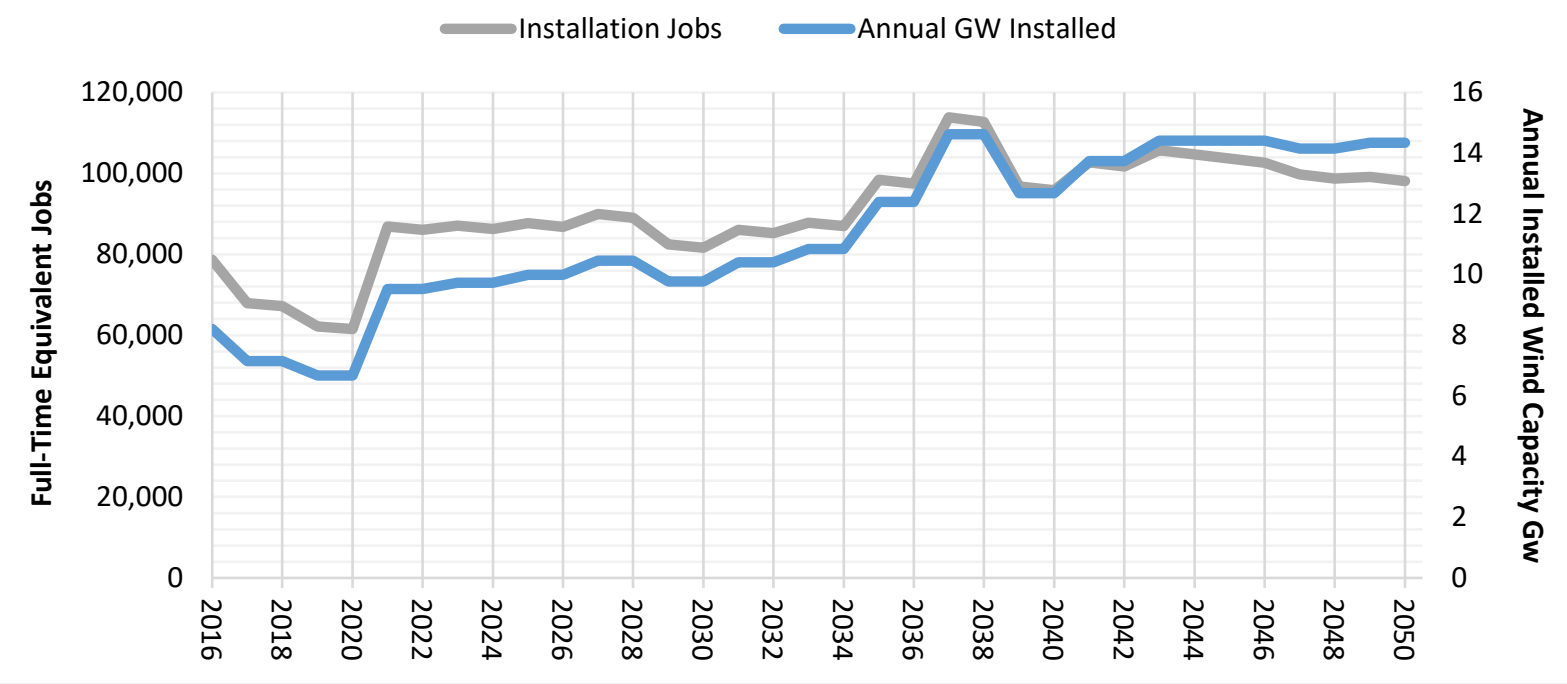

Figure 8. Estimated growth of land-based wind energy workforce (installation jobs)

An appropriately trained and educated workforce needs to be available to meet potential future employment needs. Figure 8 displays an estimate of new hires that would be needed annually if the U.S. wind energy industry achieves Wind Vision deployment levels. ${ }^{23}$ The unevenness occurs as a result of variability in jobs relating to project development, construction, and turbine manufacturing. These estimates are smoothed over a 3-year average to reflect the time it takes to plan and build new projects. The developer of a new site, for example, would contract with a turbine manufacturer to produce necessary components. The employment impact at the manufacturer could occur over several years prior to and during the physical construction.

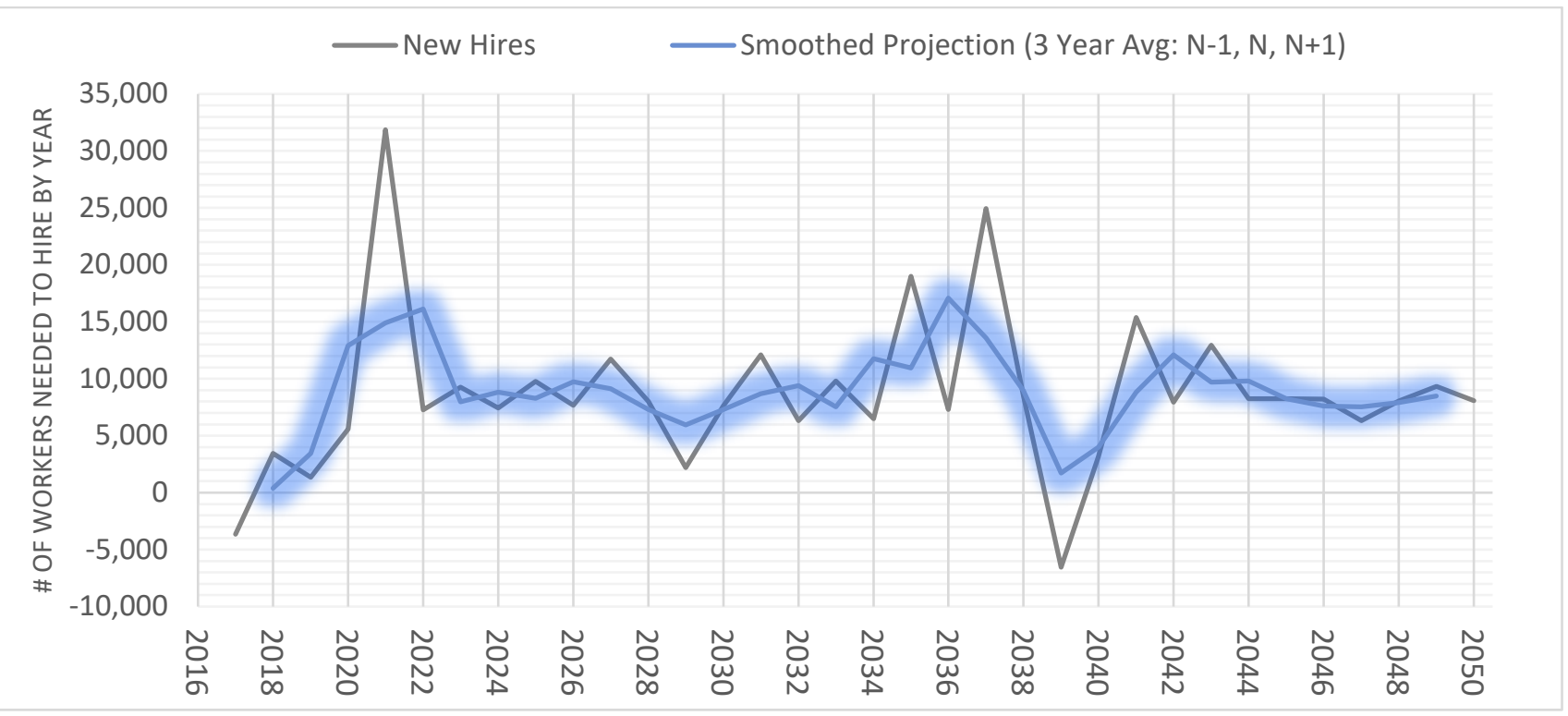

Figure 9. Estimate of new hires needed by U.S. wind energy industry

\footnotetext{
23 These are additional positions to fill, not the number of total jobs.
} 


\subsection{Wind Industry Growth Estimates by Occupation}

Construction and O\&M job numbers can be translated to occupations and associated educational attainment using data already presented in this report on the distribution of workers by occupation and education preferences expressed by employers. Table 12 shows these figures, detailing the number of graduates by degree type for each occupation. The final row shows the sums by degree program. 
Table 12. Maximum Annual New Hires Needed by Occupation Possessing Wind-Specific ${ }^{*}$ Degrees to Satisfy Employer Preference ${ }^{24}$

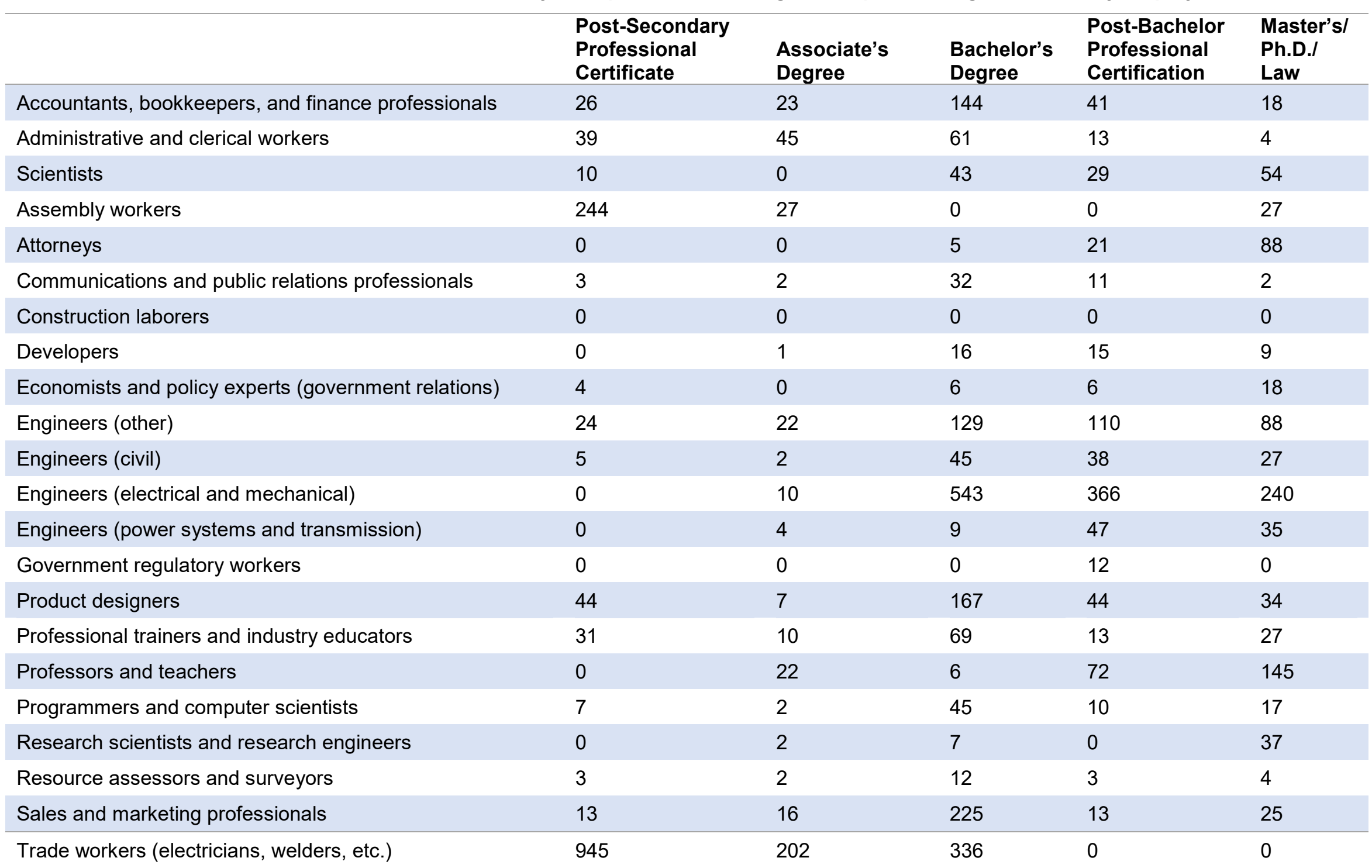

\footnotetext{
${ }^{24}$ This includes wind energy-specific degrees and certificates, as well as degrees and certificates in renewable energy that include wind.
} 


\begin{tabular}{|c|c|c|c|c|c|}
\hline & $\begin{array}{l}\text { Post-Secondary } \\
\text { Professional } \\
\text { Certificate }\end{array}$ & $\begin{array}{l}\text { Associate's } \\
\text { Degree }\end{array}$ & $\begin{array}{l}\text { Bachelor's } \\
\text { Degree }\end{array}$ & $\begin{array}{l}\text { Post-Bachelor } \\
\text { Professional } \\
\text { Certification }\end{array}$ & $\begin{array}{l}\text { Master's } \\
\text { Ph.D.I } \\
\text { Law }\end{array}$ \\
\hline Transportation and logistics workers & 62 & 0 & 0 & 0 & 0 \\
\hline Other (occupations not detailed in this study) & 336 & 126 & 373 & 152 & 158 \\
\hline Total & 2,243 & 839 & 2,490 & 1,017 & 1,056 \\
\hline
\end{tabular}




\subsection{Wind Workforce Educational Needs Based on a Wind Vision Scenario}

To estimate the education and training needs for the Wind Vision scenario, we take the future workforce estimates and occupation types and examine the known existing education and training programs and needed graduates. We analyze two cases: the baseline case and the gap reduction case. The more conservative baseline case assumes that $20 \%$ to $30 \%$ of graduates from wind education institutions enter the wind industry and 10 to 14 graduate annually, which is consistent with observations in 2016.

The higher graduation rate case, called the gap reduction case, assumes that a greater portion of students enter the wind industry. This case assumes that $60 \%$ to $65 \%$ of graduates enter the wind industry, up from the current $20 \%$ to $30 \% .{ }^{25}$ A higher percentage of graduates entering the industry reduces the number of programs with a wind component necessary to train these graduates. The data shown for the baseline case in Table 13 come from the surveys with educators and trainers.

Table 13. Baseline and Gap Reduction Cases: Percentage of Graduates Entering Wind Industry and Number of Graduates per Program per Year

\begin{tabular}{|c|c|c|c|}
\hline Degree/Certificate & Institution Type & $\begin{array}{l}\text { Baseline \% of } \\
\text { Graduates Entering } \\
\text { Wind Industry }\end{array}$ & $\begin{array}{l}\text { Gap Reduction \% of } \\
\text { Graduates Entering } \\
\text { Wind Industry }\end{array}$ \\
\hline $\begin{array}{l}\text { Post-secondary } \\
\text { professional certificate }\end{array}$ & \multirow{2}{*}{$\begin{array}{l}\text { Community and } \\
\text { technical colleges }\end{array}$} & \multirow[b]{2}{*}{$20 \%$} & \multirow[b]{2}{*}{$60 \%$} \\
\hline Associate's degree & & & \\
\hline Bachelor's degree & \multirow{3}{*}{$\begin{array}{l}\text { 4-year colleges and } \\
\text { universities }\end{array}$} & \multirow[b]{3}{*}{$30 \%$} & \multirow[b]{3}{*}{$65 \%$} \\
\hline $\begin{array}{l}\text { Post-bachelor } \\
\text { professional } \\
\text { certification }\end{array}$ & & & \\
\hline Master/Ph.D./Law & & & \\
\hline
\end{tabular}

Table 14 connects estimated demand for qualified graduates with wind energy-specific degrees to the current and future education capacity for students possessing these credentials. ${ }^{26}$ It then shows the minimum number of new programs needed, which assumes that all programs run at $100 \%$ of their capacity. ${ }^{27}$ It also shows the number of programs needed if all institutions run at the same capacities as current institutions. Students may not enroll in existing programs due to a number of reasons including admissions standards, the location of the programs, tuition, prestige of the institution, or student preferences.

\footnotetext{
25 The maximum percentage of students who can enter the industry is $100 \%$. The gap reduction range is the midpoint between the current percentage of students entering the industry and $100 \%$.

${ }^{26}$ The number of wind programs is not the same as the number of surveyees; it is adjusted to correct for nonresponse. Appendix A contains details about this adjustment.

${ }^{27}$ It is unlikely that all programs will run at $100 \%$ capacity.
} 
Even though the percentage of students not entering the wind industry was the highest at the master's, Ph.D., and law degree levels, the number of new programs at this level of education needed is not the highest. This is because even though not many of these students enter the wind industry, there is not as much demand for occupations that require that level of education compared to post-secondary and bachelor's degrees.

The focus of this analysis is to understand whether the current number of known educational and training programs offering these degrees and certificates is enough to meet potential future demand during peak years. Table 14 is under the baseline case as it compares current supply with maximum expected demand during the projection time period. This case shows that the current number of programs is not enough to support the workforce needs of the wind industry under the Wind Vision's scenario of reaching $20 \%$ wind by 2030 and $35 \%$ wind by $2050 .^{28}$

Table 14. Supply and Demand for Graduates with Wind Energy-Specific Degrees (Baseline Case)

\begin{tabular}{|c|c|c|c|c|c|c|c|c|c|}
\hline 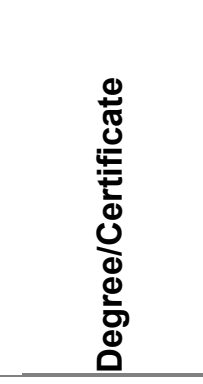 & 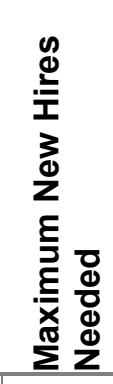 & 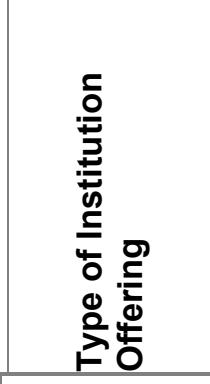 & 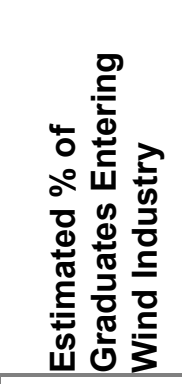 & 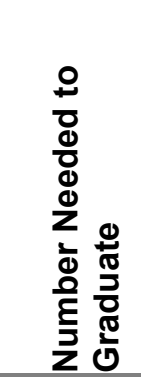 & 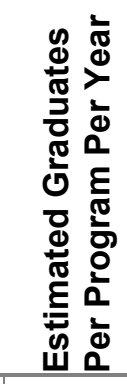 & 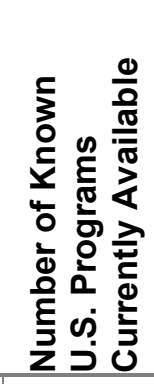 & 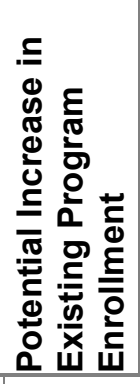 & 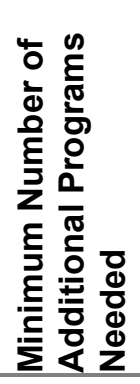 & 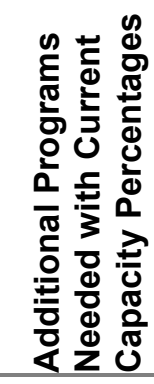 \\
\hline $\begin{array}{l}\text { Post- } \\
\text { secondary } \\
\text { professional } \\
\text { certificate }\end{array}$ & 2,250 & \multirow{2}{*}{$\begin{array}{l}\text { Community } \\
\text { and } \\
\text { technical } \\
\text { colleges }\end{array}$} & \multirow[b]{2}{*}{$30 \%$} & 7,500 & \multirow[b]{2}{*}{10} & 41 & $58 \%$ & 434 & 709 \\
\hline $\begin{array}{l}\text { Associate's } \\
\text { degree }\end{array}$ & 850 & & & 2,833 & & 50 & $68 \%$ & 119 & 233 \\
\hline $\begin{array}{l}\text { Bachelor's } \\
\text { degree }\end{array}$ & 2,500 & \multirow{3}{*}{$\begin{array}{l}\text { 4-year } \\
\text { colleges and } \\
\text { universities }\end{array}$} & \multirow[b]{3}{*}{$20 \%$} & 12,500 & \multirow[b]{3}{*}{14} & 14 & $10 \%$ & 801 & 879 \\
\hline $\begin{array}{l}\text { Post- } \\
\text { bachelor } \\
\text { professional } \\
\text { certification }\end{array}$ & 1,000 & & & 5,000 & & 17 & $73 \%$ & 190 & 340 \\
\hline $\begin{array}{l}\text { Master's/ } \\
\text { Ph.D./Law }\end{array}$ & 1,050 & & & 5,250 & & 19 & $71 \%$ & 201 & 356 \\
\hline
\end{tabular}

These figures exceed the wind capacity growth rate under the wind vision scenario because of the combination of graduates per year and the percentage of graduates who enter the wind industry. If only $30 \%$ enter the industry out of a graduating class of 10 , for example, then a single program only produces three wind workers.

\footnotetext{
28 The specific equations used to estimate these figures are in Appendix A.
} 
Table 15 shows educational needs under the gap reduction case. Even with increased graduation and entry into the wind industry, additional programs with a wind component would need to be created to meet estimated demand in the future.

The number of programs beyond those found for this study is a minimum of 28 for associate's degrees and a maximum of 258 for bachelor's degrees. At current enrollment levels and class sizes, the minimum increases to 81 for associate's degrees. The maximum increases to 305 for post-secondary - not bachelor's - due to excess capacity in post-secondary programs and the ability indicated by these institutions to expand without additional resources.

It is uncertain how many programs are needed because a number of factors can determine enrollment, not simply the existence of a program. These factors can include the location of the program, admittance requirements combined with candidate qualifications, quality or prestige of the institution, and tuition costs. Different programs will likely have varying levels of success recruiting, educating, and graduating students. The ranges presented in Tables 14 and 15 are estimates and are not necessarily set ranges of programs needed.

Furthermore, there are likely programs in existence beyond those identified in this study, reducing the number of new programs needed. The additional programs identified could exist yet were not identified. The high growth of additional programs relative to the capacity growth under the Wind Vision central scenario, then, would be mitigated - especially if unknown programs can increase capacity.

\section{For our electricity generation portfolo to reach $20 \%$ wind by 2030 in the United States, the minimum number of training and education programs beyond those identified in this study needed ranges from 570 to more than 1,700 .}

In the future, potential growth of the wind industry such as the Wind Vision scenario could increase its visibility and cause students to become more interested, give educational institutions incentive to offer the necessary courses, and lead to an industry that can hire highly qualified candidates. However, as can be seen in the workforce gap, these three events do not necessarily happen in unison. Improving information-sharing between wind industry hiring managers and graduates from training and educational programs could help mitigate the gap. 
Table 15. Supply and Demand for Graduates with Wind Energy Specific Degrees (Gap Reduction Case)

\begin{tabular}{|c|c|c|c|c|c|c|c|c|c|}
\hline 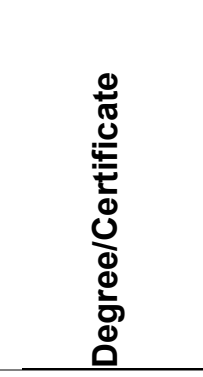 & 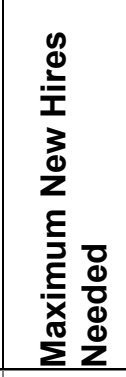 & 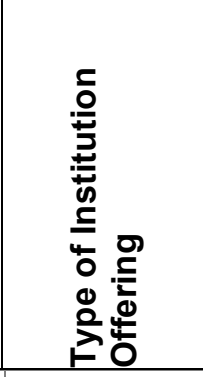 & 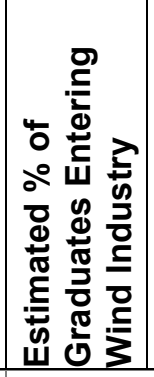 & 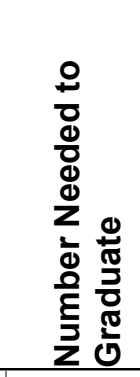 & 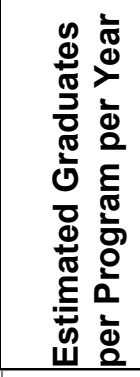 & 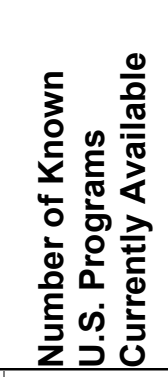 & 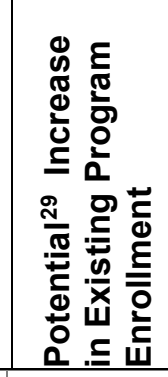 & 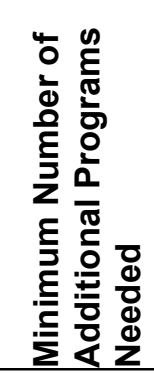 & 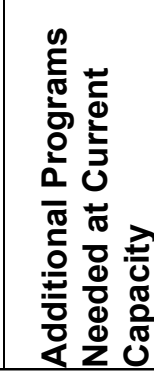 \\
\hline $\begin{array}{l}\text { Post- } \\
\text { secondary } \\
\text { professional } \\
\text { certificate }\end{array}$ & 2,250 & \multirow{2}{*}{$\begin{array}{l}\text { Community } \\
\text { and } \\
\text { technical } \\
\text { colleges }\end{array}$} & \multirow[b]{2}{*}{$65 \%$} & 3,462 & \multirow[b]{2}{*}{10} & 41 & $58 \%$ & 178 & 305 \\
\hline $\begin{array}{l}\text { Associate's } \\
\text { degree }\end{array}$ & 850 & & & 1,308 & & 50 & $68 \%$ & 28 & 81 \\
\hline $\begin{array}{l}\text { Bachelor's } \\
\text { degree }\end{array}$ & 2,500 & \multirow{3}{*}{$\begin{array}{l}\text { 4-year } \\
\text { colleges } \\
\text { and } \\
\text { universities }\end{array}$} & \multirow[b]{3}{*}{$60 \%$} & 4,167 & \multirow[b]{3}{*}{14} & 14 & $10 \%$ & 258 & 284 \\
\hline $\begin{array}{l}\text { Post- } \\
\text { bachelor } \\
\text { professional } \\
\text { certification }\end{array}$ & 1,000 & & & 1,667 & & 17 & $73 \%$ & 52 & 102 \\
\hline $\begin{array}{l}\text { Master's/ } \\
\text { Ph.D./Law }\end{array}$ & 1,050 & & & 1,750 & & 19 & $71 \%$ & 54 & 106 \\
\hline
\end{tabular}

\footnotetext{
${ }^{29}$ For the discussion on increasing the numbers of students per course, see the Education and Training Programs section and Table 10.
} 


\section{Conclusion}

Representatives from most domestic wind industry companies we surveyed experience difficulty finding qualified candidates. A lack of qualified applicants who want to work in the wind industry is one reason employers are finding it difficult to hire, and nearly one-quarter of U.S. firms look outside the United States in their job searches.

The number of programs with a wind or renewable energy component beyond those identified in this study needed to fill workforce needs under the hypothetical Wind Vision scenario at current class capacities ranges from a minimum of 570 under the gap reduction case to more than 1,700 under the baseline case. If educational institutions do not increase class sizes and maintain current capacities, the number of additional programs with a wind component needed would range from nearly 900 to more than 2,500. The types of programs needed differ between levels of education or training.

Under our baseline scenario, in which the percentage of graduates who enter the wind industry remains the same as it was at the time of the survey, a minimum of between 119 and 801 new programs would be needed. At current enrollment and class sizes, this range increases to between 233 and 879 . The highest numbers were 879 new programs needed for bachelor's degrees and 709 for post-secondary professional certificates.

Education needs could be addressed by adding entirely new programs or through the addition of wind-specific coursework or training into existing ones. New programs could be focused on renewable energy in general and have a wind component or exclusively focus on wind. Mainstreaming wind education and training curricula into existing vocational and degree programs across the country would likely reduce the gap, although this study only addresses whether a program has a wind component, not how extensive that component is.

When asked why graduates are not pursuing careers in wind energy, educational institutions primarily report that students find better opportunities elsewhere. ${ }^{30}$

The wind energy workforce gap in the United States is the gap between students who graduate and are hoping to work in the wind industry and firms that are hiring for the wind industry but cannot access the qualified new graduates. Reducing the workforce gap would require that an adequate number of students enroll in wind education programs and subsequently find jobs in the field. For this to work, educational institutions would have to add programs and recruit students, and the wind industry would need to recruit and hire qualified workers from these educational institutions.

Improved communication is one area for improvement identified by both educational institutions and industry hiring managers in this study. The wind industry can work with career counselors at high schools and post-secondary schools to make them aware of well-paying job opportunities

\footnotetext{
${ }^{30}$ In another example, students may not want to leave the region where they live, and some Americans prefer not to live in the very rural areas where wind technicians are typically employed. Not wanting to live in rural areas may prevent a graduate from entering the wind workforce, but this particular barrier to entry cannot be resolved through more programs or education. However, other barriers to potential workforce entrants have solutions that industry, academia, and government could consider.
} 
that are available to graduates or those who complete training programs. The industry can also directly advertise to candidates through career or recruiting fairs to make students aware of opportunities (including apprenticeships and internships), especially if they are not in the immediate vicinity of the school. Improved communication also includes raising awareness about the myriad of careers that support the wind industry and how different skill sets and interests can fit in. DOE's Wind Energy Technologies Office has a number of initiatives that aim to improve information-sharing and communication, and to spur innovative, interdisciplinary STEM achievement, eventually leading to a highly motivated and qualified domestic wind workforce.

\subsection{The Gap: How Is the United States Rising to the Challenge?}

DOE's Wind Energy Technologies Office has several initiatives that provide information and opportunities to help close the gap between educational institutions and industry. The following sections highlight several of the wind workforce-related topics.

\subsubsection{Wind Energy Workforce Research and Tools}

The research for this report was funded by DOE's Wind Energy Technologies Office and updates the 2012 report (Leventhal and Tegen). By collecting and reporting data at regular intervals, the U.S. wind energy industry has baseline workforce estimates and can project what might be needed (e.g., college courses, certificate programs, wind technician training) to reach future domestic workforce goals. By staying informed about what industry needs, education and training programs can better prepare students for a well-paying and meaningful career and provide their graduates with the best chances for being hired.

One tool students and other new entrants to the wind industry can use to find out where their skills and interests align with wind energy occupations is the Wind Career Map. ${ }^{31}$ This online map shows potential career pathways and links to descriptions of numerous wind industry jobs.

\subsubsection{Workforce and Education Summit}

DOE has periodically convened and facilitated a Wind Energy Workforce and Education Summit in connection with another large wind power conference (to minimize travel for attendees).

There are typically about 100 people at the summit. Participants are from education and training organizations, including community colleges and universities (graduate and undergraduate representatives). Industry experts and hiring managers also attend, and both groups bring challenges, lessons learned, and solutions to discuss at the summit. Participants have stated that this venue for in-person knowledge-sharing is valuable and has led to industry members using more inclusive hiring practices to find successful candidates.

\subsubsection{Wind for Schools}

DOE's Wind for Schools project helps develop a future wind energy workforce by encouraging students at higher education institutions to join wind energy centers of excellence at primarily land grant universities, called Wind Application Centers. ${ }^{32}$ Through the Wind Application Centers, faculty teach students about wind energy, at times having students support the

${ }^{31}$ Wind Career Map: https://www.energy.gov/eere/wind/wind-career-map

32 Wind Application Centers of Excellence: https://windexchange.energy.gov/windforschools/participants 
development and installation of small wind turbines at elementary and secondary schools. Wind for Schools supports science, technology, engineering, and math (STEM)-based engagement through organizations like KidWind ${ }^{33}$ and the National Energy Education Development Project. ${ }^{34}$ The Wind for Schools project goals are to:

- Improve wind energy workforce development through wind-focused deployment and educational activities

- Introduce teachers and students to wind energy through hands-on and academic curricula

- Equip college juniors and seniors with an education in wind energy applications

- Engage America's communities in wind energy applications, benefits, and challenges.

More than 145 small wind turbines have been installed at schools across 12 states: Alaska, Arizona, Colorado, Idaho, Illinois, Kansas, Montana, North Carolina, Nebraska, Pennsylvania, South Dakota, and Virginia. ${ }^{35}$ At the university level, hundreds of students have graduated after participating with the Wind Application Centers.

Providing educational opportunities at the primary and secondary levels is crucial to the project's aim of developing a STEM workforce for the future. Teacher training and hands-on curricula are implemented at each K-12 host school to bring the wind turbine into the classroom through interactive and interschool research tasks, engaging young people interested in STEM subjects. At the university level, the project aims to educate college students, with a focus on hands-on wind project development through classes and field work. The Wind Application Centers develop and share curricula with other schools, focusing on technical areas that are the strengths of the respective professors and institutions.

\subsubsection{Collegiate Wind Competition}

The Collegiate Wind Competition ${ }^{36}$ inspires and motivates undergraduate students, professors, and others to design, build, and test a small wind turbine at a competition with approximately 11 other universities every year. The competition challenges interdisciplinary teams of undergraduate STEM, business, and other students to offer a unique solution to a complex wind energy project using multi-faceted elements including turbine design, testing, and real-world wind project planning. This provides each student with hands-on experience as they prepare to enter the wind industry workforce. NREL, which facilitates DOE's Collegiate Wind Competition, selects schools to participate through a competitive process.

\footnotetext{
${ }^{33}$ KidWind Project: https://www.kidwind.org/

${ }^{34}$ National Energy Education Development Project: http://www.need.org/

${ }^{35}$ Interactive map of Wind for Schools turbine locations: http://en.openei.org/wiki/Wind for_Schools_Portal

${ }^{36}$ Collegiate Wind Competition: https://windexchange.energy.gov/competition
} 


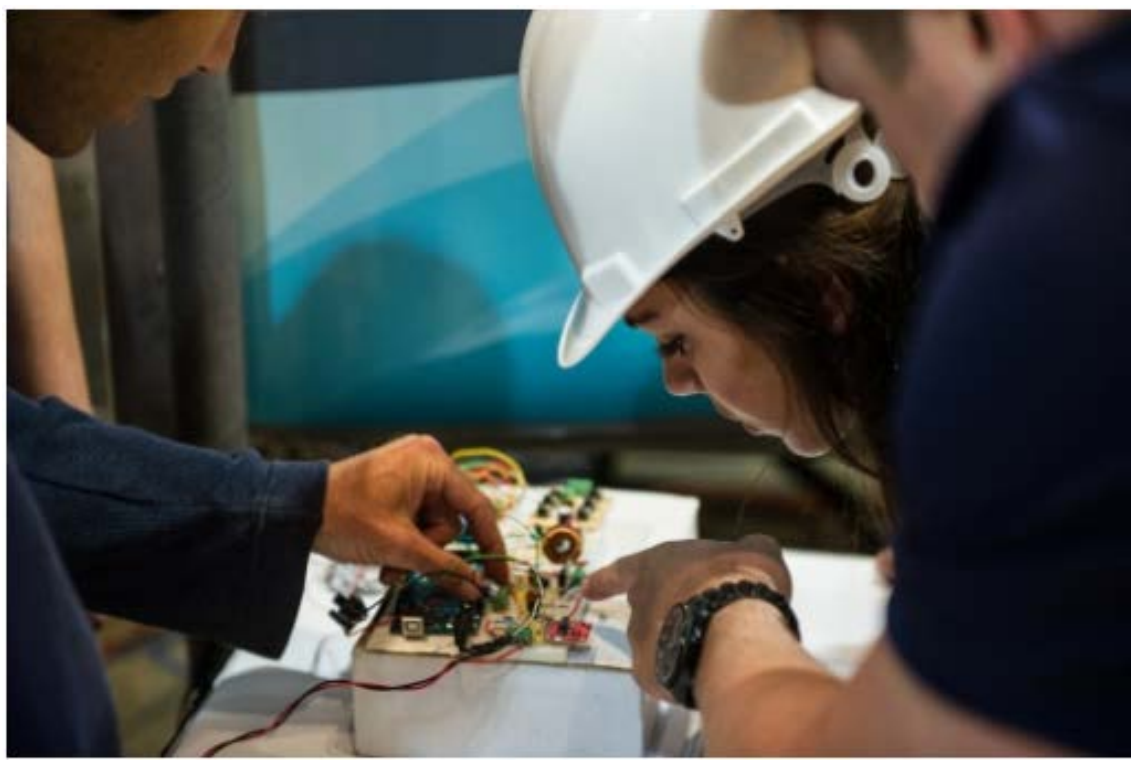

Figure 10. Students inspect wiring and electrical components on the small wind turbine they designed and built for the DOE Collegiate Wind Competition. Photo by Dennis Schroeder, NREL

\subsubsection{North American Wind Energy Academy}

The North American Wind Energy Academy was inspired by the European Academy of Wind Energy. The Academy provides a forum for graduate students and their professors to present their current results and have in-depth discussions with their future peers from around the country and the globe. North American Wind Energy Academy (NAWEA) Symposia are held every other year at a university as a low-cost option for graduate students and their professors to present and share their most current research and talk through challenges. Members of NAWEA recently published a report about wind energy graduate and undergraduate classes in the United States (Swift et al. 2018). ${ }^{37}$

\subsubsection{Domestic Wind Workforce Programs Outside of the U.S. Department of Energy}

As is common in most industries, wind energy firms provide their own training, specific to their company's methods. In addition, the American Wind Energy Association hosts a committee focusing on education and training, examining, for example, potential standards for wind technician training. However, these efforts are not integrated into nationwide training or educational programs, and there is much more room to provide meaningful connections between training, education, and industry to achieve a highly qualified domestic wind energy workforce.

\subsection{Future Work}

Several observations made from this 2016-2018 research lead to questions about why there is a domestic wind energy workforce gap. Future work that provides deeper analysis into why students choose to study wind energy and why schools open, expand, or decrease wind energy programs would be useful. Also, there are questions to ask industry representatives (in addition

\footnotetext{
${ }^{37}$ Graduate and Undergraduate University Programs in Wind Energy in the United States, December 2018. https://journals.sagepub.com/doi/full/10.1177/0309524X18818665
} 
to the ones asked for this research) that would illuminate which workers need which levels of education and which firms rely on in-house training, internships, or apprenticeships. Another potential subject for future research is to look into the education sector and try to determine whether (and how many) graduates with bachelor's degrees and higher degrees choose to work in other industries, such as solar or the utility industry-especially those who have renewable energy degrees as opposed to wind energy degrees.

Research is also needed to identify where potential wind industry employees find jobs. The characteristics of other industries that are able to recruit these workers can inform a number of questions surrounding the wind workforce gap. These can include recruiting efforts, salaries, where industries are located, the attractiveness of the wind industry in general, and a number of other characteristics. Similarly, understanding industries outside of wind that wind workers come from could lend insight into what type of experience employers value.

The wind industry is not well diversified and, to be more successful, could look to expand engagement with women and minorities. Roles of higher-level decision-makers at firms still tend to be filled by white men, whereas positions with lower pay such as administrative professional are still typically held by women (see Table 6).

Solar Ready Vets

DOE launched Solar Ready Vets in 2014 to increase veteran participation in the solar industry and help veterans transition from military to civilian careers in solar energy. DOE initiated the program in collaboration with the Solar Foundation, and it ran until 2017, graduating 526 students.

As of 2018, the U.S. Department of Defense runs the program. Programs are available at 10 Marine Corps, Army, Navy, and Air Force bases across the country. A similar initiative for wind energy could greatly benefit veterans and the domestic wind industry.

Other industries and occupations not related to the wind industry are successful in attracting candidates. Compiling these success stories can also inform what practices are most useful to attract and retain qualified candidates and good employees. Although veterans are wellrepresented in the wind industry, their skills (e.g., electrical engineer) and the wind industry's need for people with technical skills indicate that more work could be done to integrate veterans into the wind workforce. DOE and the Solar Foundation implemented Solar Ready Vets, a program in the solar energy industry that could be replicated for the wind energy industry. 


\section{References}

Energy Information Administration (EIA). 2019a. Frequently Asked Questions: What is U.S. electricity generation by energy source? Accessed from https://www.eia.gov/tools/faqs/faq.php?id=427\&t=3 April 2019.

Energy Information Administration (EIA). 2019b. EIA forecasts renewables will be the fastest growing source of electricity generation. Accessed from https://www.eia.gov/todayinenergy/detail.php?id=38053 April 2019.

Leventhal, Michael, and Suzanne Tegen. 2013. A National Skills Assessment of the U.S. Wind Industry in 2012. Technical Report NREL/TP-7A30-57512. Golden, CO: National Renewable Energy Laboratory. https://www.nrel.gov/docs/fy13osti/57512.pdf.

National Association of State Energy Officials (NASEO). U.S. Energy and Employment Report (2018). Accessed from https://www.usenergyjobs.org/.

Swift, A., Tegen, S., Acker, T. Manwell, J., Pattison, C., and McGowan, J. 2018. Graduate and Undergraduate University Programs in Wind Energy in the United States. In: Wind Engineering, December 24, 2018. https://journals.sagepub.com/doi/full/10.1177/0309524X18818665.

Tegen, Suzanne. 2016. Wind Energy Workforce Development and Jobs. Presentation NREL/PR5000-67377. Golden, CO: National Renewable Energy Laboratory. https://www.nrel.gov/docs/fy17osti/67377.pdf.

United States Census Bureau. 2018. "United States Quick Facts.” Accessed August 20, 2018. https://www.census.gov/quickfacts/fact/table/US/PST045217 May 2018.

United States Department of Veterans Affairs. 2017. "Profile of Veterans: 2015." https://www.va.gov/vetdata/docs/SpecialReports/Profile of Veterans 2015.pdf.

U.S. Bureau of Labor Statistics (BLSa). Current Employment Statistics. (2018). Accessed from https://www.bls.gov/ces/.

U.S. Bureau of Labor Statistics (BLSb). Multifactor Productivity. (2018) Accessed from https://www.bls.gov/mfp/.

U.S. Department of Energy (DOE). 2008. 20\% Wind by 2030: Increasing Wind Energy's Contribution to U.S. Electricity Supply. DOE/GO-102008-2567.

https://www.nrel.gov/docs/fy08osti/41869.pdf.

U.S. Department of Energy (DOE). 2015. Wind Vision: A New Era for Wind Power in the United States. DOE/GO-102015-4557. Springfield, VA: U.S. Department of Commerce, National Technical Information Service. https://www.energy.gov/eere/wind/maps/wind-vision. 
U.S. Department of Energy (DOE). 2017. U.S. Energy and Employment Report. Washington, DC: U.S. Department of Energy. Accessed from https://www.energy.gov/downloads/2017-usenergy-and-employment-report. 


\section{Appendix A: Estimate of U.S. Wind-Specific Degree Programs}

Representatives from 49 institutions offering 73 degrees and certificates completed these surveys. Adjusting for the facts that not all institutions on our list responded and the list is not likely to represent the full universe of programs, we derived an adjusted aggregated estimate of 141 programs (either degree or certificate), which is likely a more accurate estimate of the total number of wind-specific degree programs within the United States.

This adjustment is to reflect non-responses. We know that these non-responses offer wind or renewable energy programs, but because they did not respond we do not know specifics about their programs such as the number of graduates or the percentage of graduates entering the wind industry. In these cases, because we do not know otherwise, we assume that they are the same as the programs that did respond.

This adjustment is necessary because the conclusions of the report about the number of programs needed must factor in all existing institutions that we know of, not just the ones that responded to the survey. The number of new programs needed must include all existing programs that we know of.

We compiled the survey invitation list from programs listed in the Wind Energy Education and Training Programs database. ${ }^{38}$

Table 16. Estimate of U.S. Wind-Specific Degree Programs

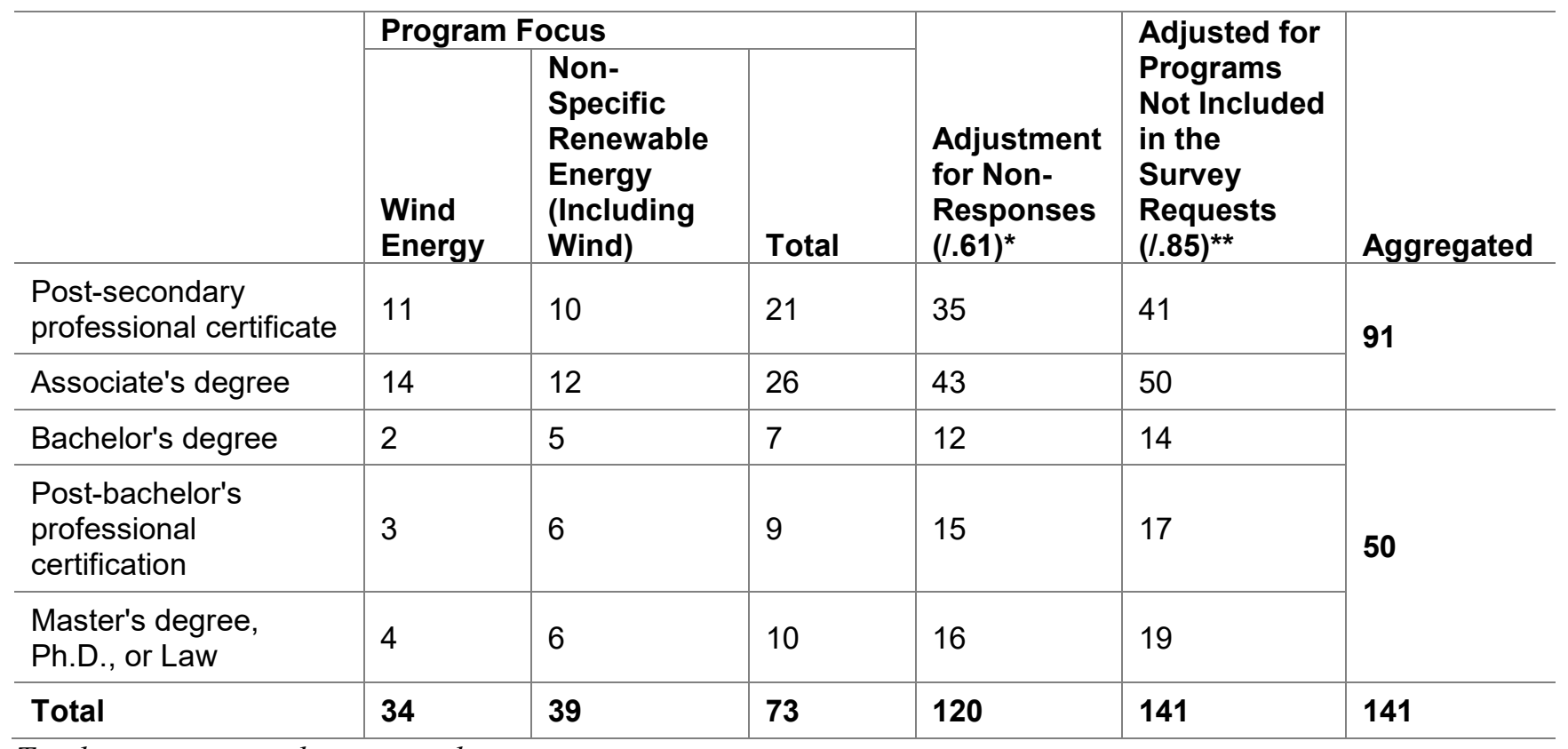

Totals may not sum due to rounding.

${ }^{38}$ https://windexchange.energy.gov/training-programs 
* Reflects the percentage of responses out of the pool of institutions identified by NREL to have a wind or renewable energy-specific program. In this case, $61 \%$ of those contacted completed the survey

** There are likely additional institutions that were not identified within the NREL sample where are referred to as the "universe" of known programs. BW Research, in its sampling, identified this as being $85 \%$ of all of the potential programs

Estimates shown in Tables 14 and 15 are based on the percentage of students who enter the wind industry, number of graduates, the number of programs currently in existence, and the ability for programs to increase student capacity. Table 17 shows the math.

Table 17. Math Used to Estimate Program Needs

\begin{tabular}{|c|c|c|c|c|c|c|c|}
\hline $\begin{array}{l}\text { Number } \\
\text { of } \\
\text { students } \\
\text { need (s) }\end{array}$ & $\begin{array}{l}\text { Percent } \\
\text { entering } \\
\text { industry } \\
\text { (i) }\end{array}$ & $\begin{array}{l}\text { Graduates } \\
\text { needed } \\
\text { (s/i) }\end{array}$ & $\begin{array}{l}\text { Estimated } \\
\text { graduates } \\
\text { each year } \\
\text { (g) }\end{array}$ & $\begin{array}{l}\text { Current } \\
\text { programs } \\
\text { available } \\
\text { (p) }\end{array}$ & $\begin{array}{l}\text { Potential } \\
\text { increase } \\
\text { in } \\
\text { capacity } \\
\text { (c) }\end{array}$ & $\begin{array}{l}\text { Minimum } \\
\text { of } \\
\text { programs } \\
\text { needed g } \\
(\mathrm{s} / \mathrm{i}) / \\
\left(\mathrm{g}^{*}(1+\mathrm{c})\right)\end{array}$ & $\begin{array}{l}\text { Total } \\
\text { needed } \\
\text { at } \\
\text { current } \\
\text { capacity } \\
\text { (s/i)/g }\end{array}$ \\
\hline
\end{tabular}




\title{
Appendix B: BW Research Method for Estimating Today's Wind Power Employees
}

\author{
$\left[\right.$ bW] $\begin{array}{l}\text { R E S E A R C H } \\ \text { PARTNERSHIP }\end{array}$
}

\section{MEMORANDUM}

To: Suzanne Tegen, Michael Leventhal, National Renewable Energy Lab

From: Ryan Young, BW Research

Date: January 17, 2017

Re: Extrapolation Methodology

Based on the sampling of wind companies conducted in November and December 2016, BW Research Partnership estimates that the nine (9) selected large commercial or utility-scale domestic wind industry segments' employ 84,151 workers. ${ }^{2}$ Of these, 69,136 are permanent wind employees, while 15,015 are temporary workers. To derive this estimate, BW Research split the employment responses by the nine (9) categories - manufacturing (including component parts manufacturing), research and development, education/training/advocacy, government/regulatory, construction, development and siting, transportation and logistics, finance/egal/insurance, and operations and asset management Mean wind employment was derived for each category and applied to industry firm ratios for the wind industry. ${ }^{3}$ The final total represents the combination of employment from each category (permanent and temporary employment).

In addition to mean employment, BW Research calculated the total number of commercial or utility scale domestic wind firms. For large organizations, the initial database (derived from AWEA membership lists, OpenEI, Windustry, NREL, and other sources) included 1,835 de-duplicated firms. A description of the process is detaled below.

Large-Wind Universe

To calculate the number of large-wind universe firms, BW Research calculated several factors to refine the database. The first of these, chum, uses a ratio of calls reaching dead air, disconnections, fast-busy, wrong number, or no business locations, to the total number of telephone attempts made. This rate of $7.66 \%$ is then applied to the total deduplicated firm database of 1,835 .

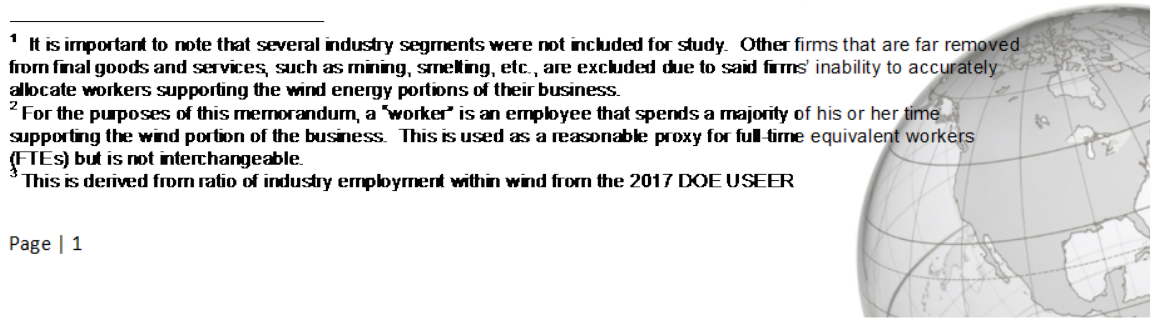




\section{$[\mathrm{bW}]$ RARTNERSHIP}

\section{MEMORANDUM}

Seventy-nine $(79)$ of the 416 respondents ${ }^{4}$ (19.00\%) reported that their firms do not conduct wind-related activities, which again is applied to the database.

Finally, 60 of the 334 firms that were asked reported that they were small firms (thereby terminating) for a rate of $17.96 \%{ }^{5}$ This rate is also applied to the de-duplicated firm database, resulting in 1,126 firms.

Based on our research in other sectors, including national solar studies, we estimate that the original database accounts for approximately $85 \%$ of the total universe. If this same rate is assumed in the current instance, the number of firms that meet the screener definition of a "wind firm" is 1,325 .

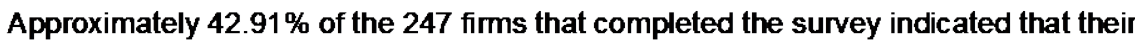
firm had multiple locations in the U.S. that conducted wind activities. Approximately three-quarters $(75.47 \%)$ of these firms answered for all of their locations. The remaining $24.53 \%$ opted to only answer the survey for their current location. The mean business locations amongst these firms was 10.7 which is used to factor their total employment. Responding firms with multiple locations that only answered for one location were more likely to be involved in the Education/Training/Advocacy, Construction, and Finance/Legal/Insurance industry segments, and were less likely to be involved in Research and Development.

Splitting firms by industry ratios and multiplying by the mean permanent and temporary wind energy employment (question 2 and question 3 ) for each of the nine (9) categories, results in 84,151 total workers. ${ }^{6}$

\section{Employment by Segment}

To derive employment by industry segment, BW Research uses the percentage of firms by industry segment ${ }^{7}$ in the wind industry multiplied by the mean permanent and temporary $50 \%$ wind employment (question 2 and question 3 ) each segment. For example, firms primarily identifying as being involved with manufacturing (including component parts) reported mean employment of 12.43 permanent and .62 temporary wind workers. Applying these means to the total estimated establishment ratios yields 12,827 permanent and 640 temporary workers, for a total of 13,467 employees in that segment.

\footnotetext{
4 That answered the screener question about wind activity

${ }^{5}$ Other factors, such as refusals, are excluded from the chum analysis.

${ }^{6}$ A further assumption is made that the $15 \%$ of firms not in the database have a simiar profile (mean) to the $85 \%$ of

fims inchuded in the database.
${ }_{7}$ This is derived from ratio of industry employment within wind from the Department of Energy's USEER Report

Page | 2
} 


\section{Appendix C: Alignment with DOE Jobs Report}

DOE contracted with BW Research to collect and analyze employment data across several major energy industries for the 2017 U.S. Energy and Employment Report. The statistical methods employed for data collection and projection in that research were superior for determining total wind energy industry employment. According to that report (p. 39):

Firms that support the nation's wind technology sector employ a total of $\mathbf{1 0 1 , 7 3 8}$ workers.

Thus, we set our wind energy industry employment totals to align with this figure of 102,000. While the 2017 U.S. Energy and Employment Report provided the best estimate for total employment, the data collected by BW Research for this report provide much finer detail of the make-up of the wind energy industry by specific occupations. Therefore, we applied the allocation of employment across occupations derived from this study to the total wind energy employment figure calculated in the aforementioned DOE report. It is for this reason that the employment figure for $2016(84,151)$ detailed in BW Research's memo contained in Appendix D does not match the 102,000 used in this report.

\section{Appendix D: BW Research Survey Text}

NREL authors have included the survey text from BW Research so that interested readers can see the questions asked. NREL authors did not edit the BW Research survey text. 


\section{NREL Wind Employer Survey - Phone Version}

Helo, my name is ___ May I please speak to a Human Rescurces Manager or person responsible for stafing at [organization]?

Hello, my name is ___ and l'm caling on behalf of the National Renewable Energy Laboratory, or NREL, who would value your participation in a brief survey about the nation's wind industry workforce.

This is the fist attempt to understand the full breadth of the wind wakforce in a systematic fashion. You help in this project is the best way that we can arive at a meaningful understanding of the workforce needs of this industry.

Your individual responses wi] not be published; only aggregated information wil be used in reporting the survey results.

(If needed): The survey should take approximately 15 minutes of you time. By answering this survey, you can help inform how investments of time and money should be made to support the industry and how to prepare the present and future wind energy labor pool based on your needs.

Screener Questions

A. What is the zip code of your current kocation?

(Accept all fve-digit responses)

(Don't Read) Refused [TERMINATE]

B. Is your company involved with an activity related to the wind energy industry? We define this as being drectly involved with researching, developing, producing, manufacturing, distributing or implementing components, goods or services related to wind energy.

\section{Yes [CONTINUE] \\ 2 No[TERMINATE]}

3 Not sUTe [TERMINATE] 
C. Please tel me if your organization participates in each of the following wind industry segments. 1=Yes, 2=No, 3=(Don't Read) Don't know/ Refused for each.

1. Manufacturing, including component parts manufacturing

2. Research and Development

3. Education/Training/Advocacy

4. Government/Regulatory

5. Construction

6. Development \& Siting

7. Transportation \& Logistics

8. Finance/LegaVInsurance

9. Operations \& Asset Management

If no to 1-9, ask:

What wind industry segment does your firm participate in?

Other (specify:

[ASK SCREENER D IF MORE THAN ONE YES AT SCREENER C]

D. Which do you consider your organization's primary focus as it relates to the wind industry? [PIPE IN YES RESPONSES FROM SCREENER C, ACCEPT ONE]

1. Manufacturing/Supply Chain/OEM

2. Research and Development

3. Education/Training/Advocacy

4. Government/Regulatory

5. Construction

6. Development \& Siting

7. Transportation \& Logistics

8. Finance/Legal/Insurance

9. Operations \& Asset Management

(SKIP SCREENER E IF SCREENER D $=\mathbf{3}$ )

E. What size systems does your firm typically work with?

Please choose one.

1 Residential or smal commercial [TERMINATE]

2 Large commercial or utifity-scale [CONTINUE]

3 (Don't Read) Don't know/ Refused [CONTINUE]

F. How many business locations does your firm have in the U.S. that conduct wind activities?

IF Screener F > 1 or Refused, ask Screener G

G. Do you feel comfortable answering questions about the hiring and staffing needs of all of your firm's locations or just your current location?

1 All locations [CONTINUE]

2 Only my location [CONTINUE SURVEY AND ALSO ASK] - Please provide us with the email address of someone at your firm who is able to answer questions about hiring and staffing at other locations so that we can send him or her a survey. 
BW Research Partnership

Collect Email:

3 No, I am not able to effectively answer questions about hiring and staffing needs - [COLLECT EMAIL ADDRESS AND THEN TERMINATE] Please provide us with the email address of someone at your firm who is able to answer questions about hiring and staffing at your firm so that we can survey him or her as well. Collect Email:

IF Screener $G=1$, state: "For the purposes of this survey, the term "firm" shall refer to all of your U.S. business locations.

If Screener $\mathrm{G}=2$ or Screener $F=1$, state "For the purposes of this survey, the term "firm" shall refer to your current business location only"

If Screener $\mathrm{G}=3$, terminate

\title{
SECTION 1 - Firm Profile
}

1. Including all full-time and part-time employees, how many permanent employees work at your firm?

\author{
Record \# of employees \\ (Don't Read) Refused
}

2. If you currently have [TAKE Q1 \#] full-time and part-time permanent employees at your firm, how many of these workers spend at least $50 \%$ of their work time supporting the wind energy portion of your business?

\section{Record \# of employees \\ (Don't Read) Refused}

[Q2 SHOULD BE LESS THAN OR EQUAL TO Q1 - BUILD IN CHECK] 
BW Research Partnership

3. How many temporary workers do you have at your firm that spend at least $50 \%$ of their work time supporting the wind energy portion of your business?

Record \# of employees

(Don't Read) Refused

\section{SECTION 2 - Workforce Development \& Training Needs}

Occupation-Related Questions

[NOTE - PLEASE COMMUNICATE TO RESPONDENT THAT WE WILL BE USING GENERAL OCCUPATIONAL TITLES RATHER THAN SPECIFIC JOB TITLES THAT MAY BE USED WITHIN EACH ORGANIZATION]

4. The next section of the survey will ask about the occupations within your organization. The occupational titles we are using may differ from the specific position titles used in your organization. For these questions, please try to equate your organization's specific position titles with the more general ones we will use here.

Please only assign one occupation to each employee. If they fall into more than one category, please assign them to the occupation in which they devote more of their time.

Please tell me if your firm employs individuals in positions matching the following general occupational titles:

$(1$ = Yes, 2 = No, 3 =DK/NA $)$

** After Screener D create a new variable titled sdprime. If only one choice selected at Screener $C$, sdprime $=$ Screener $C$ choice, If multiple choices at Screener D, sdprime=Screener D choice ** 


\begin{tabular}{|l|l|}
\hline Occupation & Field \\
\hline 1. Professors \& teachers & 2,3 \\
\hline 2. Product designers \& design engineers & 1,2 \\
\hline 3. Trade workers (electricians, welders) & $1,3,5,7,9$ \\
\hline 4. Wind technicians & 9 \\
\hline 5. Professional trainers \& industry educators & $1,3,9$ \\
\hline 6. Developer & 6 \\
\hline 7. Engineer - Civil & $1,2,4,5,6,9$ \\
\hline 8. Engineer - Electrical or Mechanical & $1,2,4,5,6,9$ \\
\hline 9. Engineer - Power Systems/ Transmission & $1,2,4,5,6,9$ \\
\hline 10. Engineer - Other & $1,2,4,5,6,9$ \\
\hline 11. Applied/field scientists (Biologists, Environmental, & $2,3,4,5,6$ \\
\hline archeologist, etc.) & \\
\hline 12. Research scientists and engineers & $1,2,3,4$ \\
\hline 13. Attorneys & $\mathrm{All}$ \\
\hline 14. Transportation/logistics workers & $1,5,7$ \\
\hline 15. Paralegals & 8 \\
\hline 16. Construction laborers & 5 \\
\hline 17. Resource assessors \& surveyors & 2,6 \\
\hline 18. Admin/clerical & $\mathrm{All}$ \\
\hline 19. Manager & $\mathrm{All}$ \\
\hline 20. Government regulatory workers & $2,3,4,8$ \\
\hline 21. Accountants/bookkeepers/finance & $\mathrm{All}$ \\
\hline 22. Assembly workers & 1 \\
\hline 23. Sales/Marketing & $\mathrm{All}$ \\
\hline 24. Programmers and Computer Scientists & $\mathrm{All}$ \\
\hline 25. Communications/PR & $\mathrm{All}$ \\
\hline 26. Economists and Policy Experts (Government relations) & $1,2,3,4,6,8$ \\
\hline & \\
\hline
\end{tabular}

For all buckets that include trade workers and specialists, ask direct follow-up but then use the more general "trade workers and specialists" in Q5-Q10:

5. What types of trade workers and specialists do you have at your company? Please include the number of each type that you have at your company. (Multiple Response) 
BW Research Parthership

\begin{tabular}{l}
\hline Electricians \\
\hline Plumbers and pipefitters \\
\hline Iron and steel workers \\
\hline Carpenters \\
\hline Sheet metal workers \\
\hline Machinists \\
\hline $\begin{array}{l}\text { Computer controlled machine } \\
\text { tool operators }\end{array}$ \\
\hline Welders \\
\hline $\begin{array}{l}\text { Construction equipment } \\
\text { operators }\end{array}$ \\
\hline Masons \\
\hline Other_specify)
\end{tabular}

Ask Q5-Q10 for three of the occupations present at Q4.

6. Thinking about the wind energy portion of your business, how many individuals do you have at your fim that are currently employed either full-time or part-time in each occupation?
A Occupation 1
B Occupation 2
C Occupation 3
D Occupation 4

\begin{abstract}
\#\#\# (Record Number)
\#\#\# (Record Number)

\#\#\# (Record Number)

\#\#\# (Record Number)
\end{abstract}

CONTINUE FOR AS MANY OCCUPATIONS IN EACH CATEGORY

[CREATE INTERNAL CONTROL SO THAT THE COMBINED OCCUPATINAL EMPLOYMENT IS NOT MORE THAN OVERALL WIND FOCUSED EMPLOYMENT Q2]

7. Please indicate the level of difficulty your firm has in finding qualified applicants who meet the organization's hiring standards.

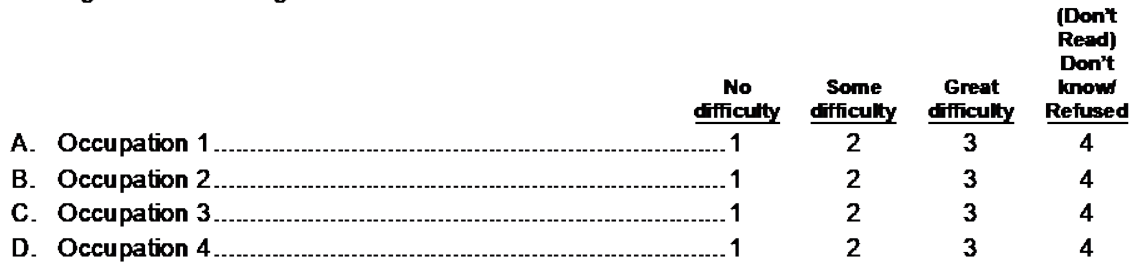


BW Research Parthership

8. For each occupation, please tell me the preferred educational attainment for new hires.

1 High school diploma or less

Post secondary professional certificate (joumeyman, trade/technical programs)

Associate Degree

Bachelor Degree

Post Bachelor professional certification (examples: CPA, PE, LEED)

Master Degree

PhD or Professional Degree

8 (Don't Read) Don't know/ Refused

9. Thinking about the different types of [pipe in occupation] that work in the wind energy portions of your business, do any of these individuals require the following skills sets or educational certifications, and if so are they somewhat important or very important?

RANDOME

(Don't Read)

\begin{tabular}{|c|c|c|c|c|}
\hline & Required & Preferred & $\begin{array}{l}\text { Neither } \\
\text { Requied nor } \\
\text { Preferred }\end{array}$ & DKNA \\
\hline A. & 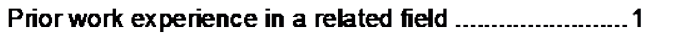 & 2 & 3 & 4 \\
\hline B. & Prior work experience specifically in Whd Energy ...... 1 & 2 & 3 & 4 \\
\hline c. & $\begin{array}{l}\text { Wind Energy specific training (including courses, } \\
\text { workshops, conferences, etc) }\end{array}$ & 2 & 3 & 4 \\
\hline D. & Professional Certification in their occupation ............... 1 & 2 & 3 & 4 \\
\hline E. & Wind Energy specific Professional Certification ........... 1 & 2 & 3 & 4 \\
\hline F. & College Degree. 1 & 2 & 3 & 4 \\
\hline G. & Wind Energy specific college degree & 2 & 3 & 4 \\
\hline
\end{tabular}

10. For each of the following occupations, please tell me any specific training credentials that you deem valuable.

[open end for each occupation]

11. Has your firm reviewed any applicant resumes or conducted any interviews with applicants outside of the U.S. for your U.S.-based wind positions? [frequency of firms searching outside U.S.]

a. Yes (specify countries)

b. No

c. DKNA

[IF Q10=a, ask Q11 \& 12, otherwise SKIP to Q13]

12. Has your firm hired any foreign nationals for U.S.-based wind positions at your fim, through $\mathrm{H} 1-\mathrm{B}$ visa or other programs, in the last 24 months? [this tells you frequency of firms hiring outside US]
a. Yes (specify countries)
b. No

c. DKNA

[If $\mathrm{Q} 1$ or $\mathrm{Q} 2=\mathrm{a}$, ask $\mathrm{Q} 12$ otherwise SKIP] 
BWW Reseanch Partunership

13. Please indicate your agreement with the following statements comparing U.S. applicants for wind-related positions compared to intemational applicants?

For each, indicate strongly agree, somewhat agree, neither agree nor disagree, somewhat disagree, strongly disagree, don't know

a. U.S. applicants have more problem solving and critical thinking skils than their intemational counterparts

b. U.S. applicants have less wind-related experience than their intemational counterparts

c. U.S. applicants have a stronger work ethic than their intemational counterparts

d. U.S. applicants have less specific education and training specific to the wind industry than their international counterparts

14. For each of the following wind energy occupations we have discussing I would lke to know how many are women.

A. How many of your firms [Pipe in 95 response for occupation \#1] - [Occupation 1 Title] in Whd Energy are women? [IF NEEDED, This includes full-time and part-time employees]

Record \# of women for each occupation

(Don't Read) Don't know/ Refused

B. How many of your firms [Pipe in q5 response for occupation \#1] - [Occupation 2 Title] in Whd Energy are women? [IF NEEDED, This includes full-time and part-time employees]

Record \# of women for each occupation

(Don't Read) Don't know/ Refused

C. How many of your firms [Pipe in q5 response for occupation \#1] - [Occupation 3 Title] in Whd Energy are woman? [IF NEEDED, This includes full-time and part-time employees]

Record \# of women for each occupation

(Don’t Read) Don't know/ Refused

15. For each of the following wind energy occupations we have discussing I would like to know how many are ethnic or racial minorities.

A. How many of your firms [Pipe in q5 response for occupation \#1] - [Occupation 1 Title] in Whd Energy are ethnic or racial minorities? [IF NEEDED, This inchudes full-time and part-time employees]

Record \# of ethnic/racial minorities for each occupation (Don't Read) Don't know/ Refused

B. How many of your firms [Pipe in 95 response for occupation \#1] - [Occupation 2 Title] in Whd Energy are ethnic or racial minorities? [IF NEEDED, This includes full-time and part-time employees]

Record \# of ethnic/racial minorities for each occupation

(Don't Read) Don't know/ Refused 
BWW Reseanch Partunership

C. How many of your firms [Pipe in 95 response for occupation \#1] - [Occupation 3 Title] in Whd Energy are ethnic or racial minorities? [IF NEEDED, This includes full-time and part-time employees]

Record \# of ethnic/racial minorities for each occupation

(Don't Read) Don't know/ Refused

16. For each of the following wind energy occupations we have discussing I would like to know how many are veterans of the U.S. Armed Forces.

A. How many of your firms [Pipe in 95 response for occupation \#1] - [Occupation 1 Titte] in Wind Energy are veterans? [IF NEEDED, This includes full-time and part-time employees]

Record \# of veterand for each occupation

(Don't Read) Don't know/ Refused

B. How many of your firms [Pipe in q5 response for occupation \#1] - [Occupation 2 Title] in Wind Energy are veterans? [IF NEEDED, This includes ful-time and part-time employees]

Record \# of veterans for each occupation

(Don't Read) Don't know/ Refused

C. How many of your firms [Pipe in q5 response for occupation \#1] - [Occupation 3 Titte] in Wind Energy are woman? [IF NEEDED, This includes full-time and part-time employees]

Record \# of veterans for each occupation

(Don't Read) Don't know/ Refused

\section{SEC TION 3 - Revenue Question}

17. Approximately how much of your firm's work, in terms of total revenue, is related to wind energy products or services?

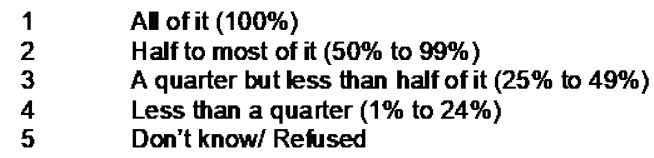

\section{SECTON 5 - Permission Questions}

18. Are you interested in receiving future information about the findings of this research?

1 Yes

2 No

19. Would you be willing to be contacted by educators and researchers to participate in a followup interview regarding this research?

$\begin{array}{ll}1 & \text { Yes } \\ 2 & \text { No }\end{array}$


BW Research Partinerahip

Thank you for completing the survey. Since it sometimes becomes necessary for the project manager to confirm responses to certain questions, please verify your contact information.

A. First and Last Name

B. Position

C. Phone

D. Emat

E. Company Name

F. Company Address

G. Company City

H. Company State

I. Company Zip

Thank you very much for your time.

J. Survey Date 